$\underline{\text { Review Article }}$

\title{
Proteolytic Processing of Von Willebrand Factor by Adamts13 and Leukocyte Proteases
}

Stefano Lancellotti, Maria Basso and Raimondo De Cristofaro*

Institute of Internal Medicine and Geriatrics, Haemostasis and Thrombosis Center, Catholic University School of Medicine, ROMA - ITALY

Correspondence to: Prof. Raimondo De Cristofaro. Institute of Internal Medicine and Geriatrics, Physiopathology of Haemostasis Research Center, Catholic University School of Medicine. Largo F. Vito, 1 - 00168 Roma - Italy. Tel. +39-0630154438 - Fax +39-0630155915. E-mail: rdecristofaro@rm.unicatt.it

Competing interests: The authors have declared that no competing interests exist.

Published: Septembetr 2, 2013

Received: July 10, 2013

Accepted: August 20, 2013

Citation: Mediterr J Hematol Infect Dis 2013, 5(1): e2013058, DOI: 10.4084/MJHID.2013.058

This article is available from: http://www.mjhid.org/article/view/11980

This is an Open Access article distributed under the terms of the Creative Commons Attribution License (http://creativecommons.org/licenses/by/2.0), which permits unrestricted use, distribution, and reproduction in any medium, provided the original work is properly cited.

Abstract. ADAMTS13 is a $190 \mathrm{kDa}$ zinc protease encoded by a gene located on chromosome 9q34. This protease specifically hydrolyzes von Willebrand factor (VWF) multimers, thus causing VWF size reduction. ADAMTS13 belongs to the A Disintegrin And Metalloprotease with ThromboSpondin type 1 repeats (ADAMTS) family, involved in proteolytic processing of many matrix proteins. ADAMTS13 consists of numerous domains including a metalloprotease domain, a disintegrin domain, several thrombospondin type 1 (TSP1) repeats, a cysteine-rich domain, a spacer domain and 2 CUB (Complement c1r/c1s, sea Urchin epidermal growth factor, and Bone morphogenetic protein) domains. ADAMTS13 cleaves a single peptide bond (Tyr1605-Met1606) in the central A2 domain of the VWF molecule. This proteolytic cleavage is essential to reduce the size of ultra-large VWF polymers, which, when exposed to high shear stress in the microcirculation, are prone to form with platelets clumps, which cause severe syndromes called thrombotic microangiopathies (TMAs). In this review, we a) discuss the current knowledge of structurefunction aspects of ADAMTS13 and its involvement in the pathogenesis of TMAs, b) address the recent findings concerning proteolytic processing of VWF multimers by different proteases, such as the leukocyte-derived serine and metallo-proteases and c) indicate the direction of future investigations.

Introduction. The discovery of the metalloprotease referred to as ADAMTS13 (A Disintegrin-like $\underline{\text { And }}$ Metalloprotease with Thrombospondin type 1 motif $\underline{13}$ ), as many other examples in biomedical research, found its way in the attempt to address the issue concerning the pathogenesis of severe forms of thrombotic microangiopathies (TMAs). The latter are a group of severe diseases characterized by deposition of blood platelet thrombi in the microcirculation, responsible for potentially fatal multi-organ failure. Moake et al. ${ }^{1}$ reported in 1982 the first evidence that the pathogenesis of the main form of microangiopathy, that is Thrombotic Thrombocytopenic Purpura (TTP), arises from a defect in proteolytic processing of von 
Willebrand factor (VWF), a multimeric glycoprotein with very high molecular weight that plays an essential role in platelet-dependent hemostasis. In 1996, 2 groups independently reported a metalloprotease that specifically cleaves VWF at the Tyr1605-Met1606 bond in the A2 domain. ${ }^{2,3}$ The proteolytic activity required VWF in a denatured conformation, achieved by preincubation with either low-concentration guanidine- $\mathrm{HCl}^{3}$ or urea, ${ }^{2}$ or by exposure to high shear stress in vitro. ${ }^{3}$ The proteolysis also required divalent cations such as $\mathrm{Ba} 2+, \mathrm{Zn} 2+, \mathrm{Ca} 2+$ or $\mathrm{Co} 2+.^{3} \mathrm{~A}$ few years later, the protease was cloned, purified and characterized, and several groups identified the VWFcleaving protease as ADAMTS13, a novel member of the ADAMTS family of metalloproteases. ${ }^{4-8}$ Considerable evidence now implicates the haemostatic protein VWF as a key component in TTP pathogenesis. ${ }^{9} \quad$ VWF is an abundant plasma glycoprotein synthesized in all vascular endothelial cells and megakaryocytes as a precursor containing a signal peptide and large propeptide. ${ }^{10,11}$ Endothelial cell VWF is secreted via both constitutive and regulated pathways. In response to a variety of stimuli, VWF is released from endothelial cells as ultra-large (UL)VWF, which can be up to approximately $20,000 \mathrm{kDa}$ in size $^{12,13}$ and are the most adhesive and reactive forms of VWF. UL-VWF form string-like structures attached to the endothelial cell surface, perhaps through interaction with P-selectin. ${ }^{14}$ Under fluid shear stress, the UL-VWF strings are cleaved by ADAMTS13 at the Tyr1605-Met1606 bond in the A2 domain ${ }^{3}$ to generate the range of VWF multimer sizes that normally circulate in the blood. VWF serves as the primary adhesive link between platelets and subendothelium and it also carries and stabilizes coagulation factor VIII (FVIII) in the circulation. These hemostatic functions depend upon the ability of VWF to bind circulating factor VIII, subendothelial collagens, platelet glycoprotein Ib $\alpha(\mathrm{GPIb} \alpha)$ and integrin $\alpha \mathrm{IIb} \beta \mathrm{III}$, but the regulation of platelet adhesion depends upon cleavage of VWF multimers by ADAMTS13 (Figure 1). ${ }^{15}$ However, VWF in plasma adopts a folded globular conformation that does not bind to platelet GPIb $\alpha$ and is not cleaved by ADAMTS13. ${ }^{16}$ Fluid shear stress, ${ }^{17}$ or binding to certain surfaces, changes the conformation of VWF so that it assumes an elongated form, disclosing the buried binding site for platelet GPIb $\alpha$, localized in the A1 domain of the protein. Upon this physically-induced conformational transition, VWF multimers bind tightly to platelet GPIb $\alpha$ and, at the same time, can be recognized by ADAMTS13. A similar modulating effect in vitro is achieved by including antibiotic ristocetin or by denaturing reagents such as urea and guanidine- $\mathrm{HCl}^{2,3,18,19}$ The stretched conformer of VWF, more prone to ADAMTS13 proteolysis, is stabilized in vivo through the interaction with P-selectin. ${ }^{20}$ Inability to cleave the newly released UL-VWF multimers ${ }^{1,21,22}$ owing to hereditary or acquired deficiency of plasma ADAMTS13 activity may induce spontaneous VWF-dependent platelet adhesion and aggregation, ${ }^{23}$ leading to disseminated microvascular thrombosis as seen in patients with TTP.

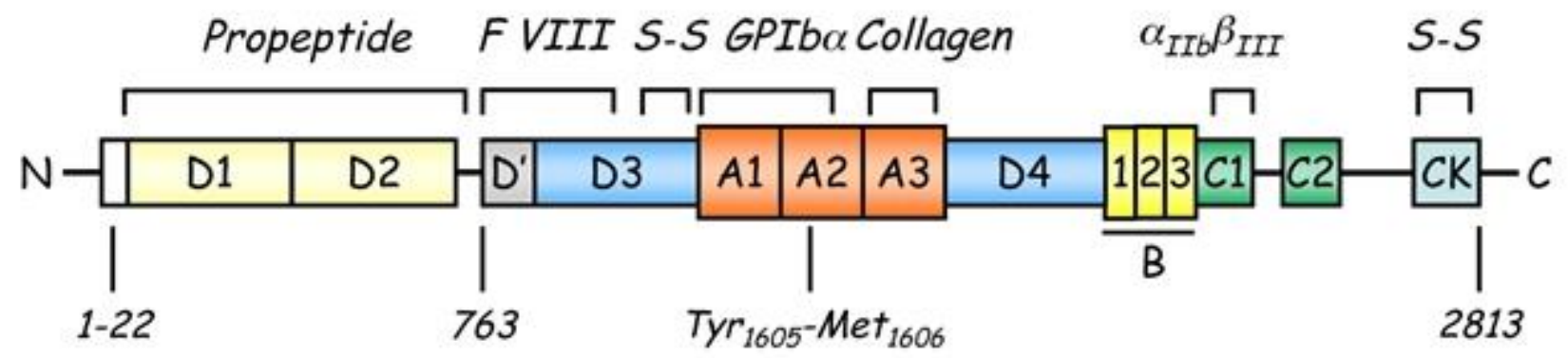

Figure 1. Scheme of von Willebrand factor monomer molecule with its functional domains. The prepro-VWF polypeptide is indicated with amino acids numbered from the amino- (aa 1) to carboxy-terminal portions (aa 2813). Binding sites are indicated for factor VIII (D' and D3 domains), platelet glycoprotein Ib $\alpha$ (GPIb $\alpha$ ) (A1 domain), collagen (A1 and A3 domains) and integrin $\alpha$ IIb $\beta$ III (RGDS sequence within the C1 domain). The cleavage site (Tyr1605-Met1606) for ADAMTS13 is located at the central A2 domain of von Willebrand factor. The locations of intersubunit disulfide bonds (S-S) are shown in the CK and D3 domains, which are important for the formation of VWF dimers and multimers, respectively.

ADAMTS13 Structure and Function. The human ADAMTS13 gene is located on chromosome 9 at position 9q34. It spans $37 \mathrm{~kb}$ in length and contains 29 exons. ${ }^{6,8}$ ADAMTS13 mRNA is approximately $5 \mathrm{~kb}$ and encodes a 1427 amino acid protein. Several alternatively spliced mRNA variants have been characterized; their significance remains unknown. ${ }^{6,8}$ The predicted molecular weight of $145 \mathrm{kDa}$ differs from the observed molecular mass of purified plasma ADAMTS13 $(\sim 190 \mathrm{kDa}),{ }^{24,25}$ and this difference is likely due to its extensive glycosylation. ${ }^{26}$ ADAMTS13 is synthesized predominantly in liver, ${ }^{6-8,25}$ although variable expression has been observed in endothelial cells, ${ }^{27,28}$ endothelial glomerular cells ${ }^{29}$ megakaryocytes or platelets ${ }^{30,31}$ and secreted into plasma as an already active enzyme. Mutations in the ADAMTS13 gene $^{27}$ may result in a reduced or an aberrant secretion of ADAMTS13 protein into the circulation. Various truncated forms of ADAMTS13 are detectable in plasma, ${ }^{32}$ perhaps owing to alternative splicing of 
ADAMTS13 mRNA or proteolysis of ADAMTS13 by serine proteases such as thrombin ${ }^{33}$ and leukocyte elastase. ${ }^{34}$ Human placenta and skeletal muscle synthesize a $2.4 \mathrm{~kb}$ ADAMTS13 mRNA. $^{8}$ There are some evidences from in vivo ${ }^{35,36}$ and in vitro ${ }^{36,37}$ studies that ADAMTS13 mRNA and protein are produced in liver hepatic stellate cells. However, the contribution of hepatic stellate cells to plasma levels of ADAMTS13 remains to be determined. Considering the large surface area of vascular endothelial beds, plasma ADAMTS13 might be derived mainly from endothelial cells even though each endothelial cell produces little amounts of ADAMTS13 compared to hepatic stellate cells. $^{27,28}$ ADAMTS13 is the $13^{\text {th }}$ member of the ADAMTS family of zinc proteases, which is related to the large ADAM (A Disintegrin And Metalloprotease) family. The ADAMTS family of zinc metalloproteases contains 19 members that share the common structure of a hydrophobic signal sequence, a propeptide, a metalloprotease domain, a thrombospondin type 1 (TSP1) repeat, a disintegrin-like domain, a cysteinerich domain and a spacer domain. ${ }^{6,8}$ In contrast to ADAM proteases, ADAMTSs lack EGF-like repeats and a transmembrane domain and, therefore, are secreted rather than membrane bound enzymes. In addition, all ADAMTS family members possess one or more thrombospondin type 1 (TSP1) motifs ${ }^{38}$ and variable additional $\mathrm{C}$-terminal domains. The carboxyl terminus of ADAMTS13 contains seven more TSP1 repeats and two CUB domains, which are named after motifs first identified in Complement components $\mathrm{C} 1 \mathrm{r}$ and $\mathrm{C} 1 \mathrm{~s}$, sea urchin protein Uegf and Bone morphogenetic protein-1(Figure 2). ${ }^{39}$

Globally, the family of ADAMTS is composed of enzymes whose main functions include: (1) collagen processing; (2) cleavage of the matrix proteoglycans aggrecan, versican and brevican; (3) inhibition of angiogenesis; and (4) blood coagulation homoeostasis as the von Willebrand factor cleaving protease. Roles in organogenesis, inflammation and fertility are also apparent. Some ADAMTS genes have been found to show altered expression in arthritis and various types of cancer. For instance, ADAMTS2 cleaves the propeptide of collagen II, and mutations in this protein are responsible for the Ehlers-Danlos syndrome type VII C. ${ }^{40}$ Mutations in ADAMTS10 cause autosomal recessive Weill-Marchesani syndrome, a connective tissue disorder characterized by abnormalities of the lens of the eye, proportionate short stature, brachydactyly and joint stiffness. ${ }^{41}$ ADAMTS1, ADAMTS4 and ADAMTS5/11 (also known as aggrecanases) cleave the cartilage proteoglycan aggrecan and may play a role in inflammatory joint disease. ${ }^{42-44}$ Interestingly, an anti-inflammatory role has also been recently attributed to ADAMTS $13 .{ }^{45}$ Since the isolation and cloning of the ADAMTS13 cDNA, several laboratories have expressed recombinant ADAMTS13 in cell culture. Recombinant ADAMTS13

\section{$A D A M$}

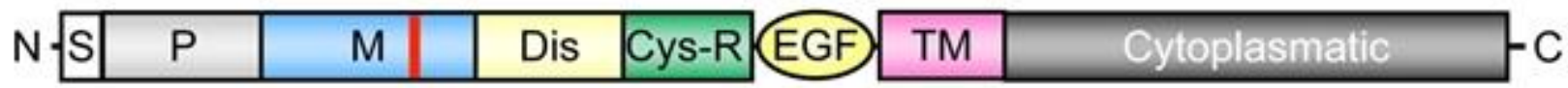

ADAMTS

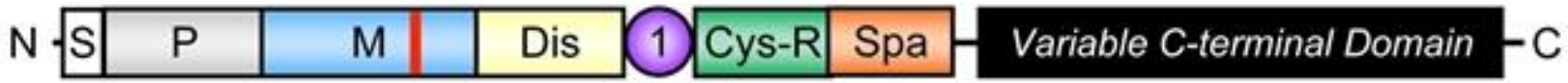

\section{ADAMTS13}

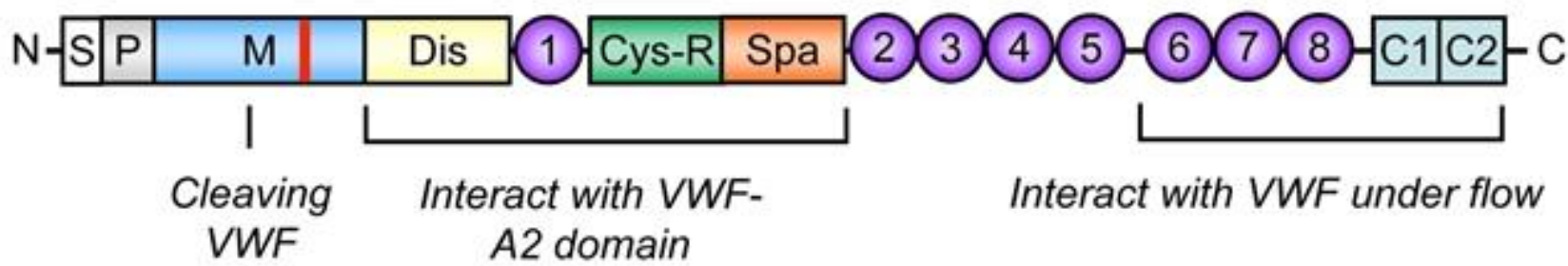

Figure 2. Schematic diagram of ADAM, ADAMTS and ADAMTS13 structure. The structural domains are indicated: signal peptide (S), propeptide $(\mathrm{P})$, metalloprotease (M) (location of zinc-binding motif shown in red), disintegrin domain (Dis), first thrombospondin type 1 (TSP1) repeat (1), cysteine-rich domain (Cys-R), spacer domain (Spa), the second to eighth TSP1 repeats(2) through (8) and two CUB domains (C1 and C2). The metalloprotease domain is the catalytic center that cleaves von Willebrand factor (VWF). The proximal carboxylterminal domains from Dis to Spa interact with the A2 domain of VWF. More distal carboxyl-terminal domains (TSP1 2-8) interact with VWF under fluid shear stress. EGF indicates epidermal growth factor-like repeat and TM, transmembrane domain. 
cleaves VWF in vitro, providing a formal demonstration that ADAMTS13 is indeed the VWFcleaving protease identified in earlier studies. ${ }^{25,26}$ The detailed structure of the full-length ADAMTS13 molecule is not yet solved. Only recently, the X-ray diffraction map of the recombinant ADAMTS13 fragment composed of the thrombospondin-1 (TSP-1) type-1 repeat domain $(\mathrm{T})$, the cysteine-rich $(\mathrm{C})$ region, and the spacer domain (S) has been reported. ${ }^{46}$ Very recently, the crystal structure of the P475S mutant of ADAMTS13-DTCS (DTCS-P475S, residues 287-685) was solved and compared with the wild-type structure. ${ }^{47}$ The propeptide of ADAMTS13 contains 41 amino acids, in contrast to the approximately 200 amino acids that comprise the propeptides of most other members of ADAM and ADAMTS family. ${ }^{48,49}$ Like other proteases, ADAMTS13 propeptide presents a typical proprotein processing site (RQRR), which has been shown to be a furin cleavage site. ${ }^{8}$ At variance with what has been observed for other metalloproteases, deletion of the ADAMTS13 propeptide does not impair secretion or enzymatic activity, demonstrating that the propeptide is not required for folding or secretion and likely does not confer enzymatic latency. ${ }^{49}$ Moreover, it has been shown that a mutation in the furin consensus recognition site leads to secretion of an active proADAMTS13. ${ }^{49}$ Detection of anti-propeptide antibodies in some patients with TTP suggests that not all plasma ADAMTS13 has this sequence removed. ${ }^{50}$ The metalloprotease domain of ADAMTSs consists of about 200 amino acids. The structural relationship of ADAMTSs to other zinc matrix metalloproteinases (MMPs) is shown in Figure 3. ADAMTSs are reprolysin-like proteins, which, together with ADAMs, MMPs, astacins and serralysins, constitute the metzincin superfamily. The catalytic domains of ADAMTS proteinases share a high degree of similarity and contain the zinc-binding sequence, in which the catalytic $\mathrm{Zn} 2+$ ion is coordinated by the three histidine residues, "H224EXXHXXGXXHD235", where ' $X$ ' represents any amino acid residue and the conserved aspartic acid residue distinguishes the ADAMs and ADAMTSs from other metalloproteinases. The glutamate following the first zinc-binding histidine has a catalytic role, ${ }^{51}$ polarising a water molecule through hydrogen bonding, which is stabilised by coordination with the $\mathrm{Zn} 2+$ ion and is responsible for the nucleophilic attack on the carbonyl of the substrate scissile peptide bond. ${ }^{52,53,54}$ As in all MMPs and adamalysins, the zinc-binding sequence is followed a short distance from the C-terminal end (10-20 amino acids after the third histidine), ${ }^{55}$ by a conserved methionine residue, an active-site arrangement that has been termed 'metzincin-type'. This methionine constitutes the 'Met-turn', a tight turn arranged as a right-handed screw that seems to serve an important function in the structure of the active site ${ }^{53}$ It could form indeed a hydrophobic base beneath the catalytic $\mathrm{Zn}^{2+}$. Different studies using C-terminal truncations of recombinant ADAMTS13 have shown that the metalloprotease domain alone was not able to cleave plasma VWF. ${ }^{49,56,57}$

Truncation of ADAMTS13 within or distal to TSP1 results in generation of enzymes that retain VWFcleaving activity in vitro, while truncations proximal to TSP1 (within the protease, TSP1, cysteine-rich or spacer domains) result in an inactive protein. These Zinc Metalloproteinases
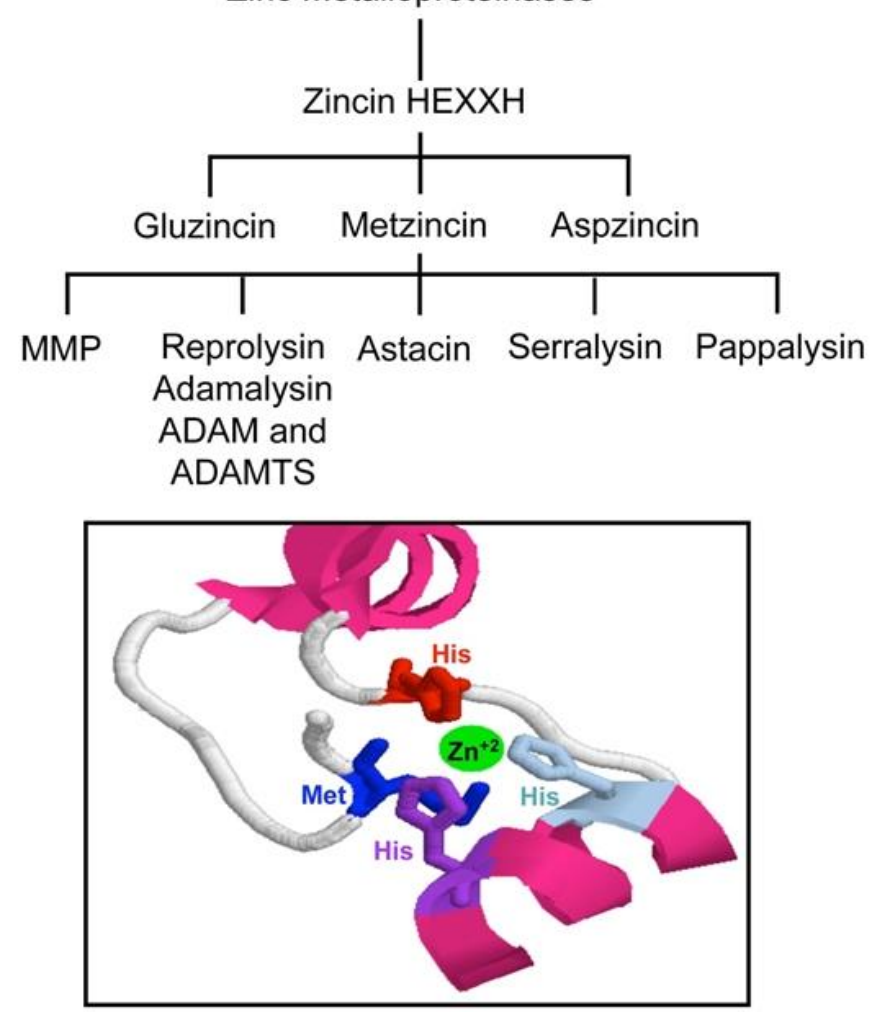

Figure 3. The zinc metalloproteinases of the zincin type that have the minimal catalytic zinc-binding motif containing two histidine residues flanking the catalytic glutamate, $\mathrm{HEXXH}$, comprise three superfamilies: the gluzincins, the aspzincins and the metzincins. Within the metzincins, the major families are the matrixins or matrix metalloproteinases (MMPs), the reprolysins (also known as adamalysins, which includes some ADAM (a disintegrin and metalloproteinase) and ADAMTs (ADAMs with thrombospondin repeats proteins) and the astacins. Metzincins have an HEXXHXXGXXHZ...M motif with three histidine residues binding the zinc ion and an invariant methionine turn in the active site that generates the name metzincins. $X$ represents any amino acid residue and $\mathrm{Z}$ indicates a subfamily specific conserved residue, which is D for both ADAM and ADAMTS members. (Inset) Homology modeling of the metalloproteinase (M) domain of ADAMTS-13. The structure was generated using the program RasMol vs. 2.7.5. The structure of the polypeptide chain 80-290, corresponding to the M-domain of ADAMTS13 was modeled by homology on the crystallographic structure of ADAMTS4 solved at $2.80 \AA$ (PDB entry code: 2RJP). Zinc ion (green) is shown together with the three catalytic His-residues. The "Met-turn" typical of the metzincin family is also indicated. 
results indicate that the protease domain alone, even if functional, is not sufficient to recognize and specifically cleave the VWF cleavage site, suggesting that sequences within the region spanning the protease domain to the spacer domain of ADAMTS13 are necessary for VWF-cleaving activity, at least in vitro. The mechanistic aspects driving the molecular recognition and cleavage of VWF by ADAMTS13 have been recently unraveled in elegant studies. ${ }^{33,58}$ These studies showed that the domains between the metalloprotease and the spacer domain are critical for substrate recognition and cleavage because the mutants lacking one or more of these domains do not cleave multimeric VWF. ${ }^{57}$ Modulation of the ADAMTS13/VWF interaction is critical for an efficient proteolysis and involves both VWF and ADAMTS13. The latter binds to VWF under static conditions and under both venous $\left(2.5 \mathrm{dyn} / \mathrm{cm}^{2}\right)$ and arterial $\left(30 \mathrm{dyn} / \mathrm{cm}^{2}\right)$ shear stress. This interaction, however, is unproductive for proteolysis unless shear stress is high enough to stretch VWF and expose the buried A2 domain for cleavage. ${ }^{17,59}$ Under static conditions, ADAMTS13 cleaves VWF only under denaturing conditions, ${ }^{2,3}$ or in the presence of the antibiotic ristocetin ${ }^{60}$ whereas under conditions of high shear stress found in the microvasculature, VWF proteolysis is extremely rapid and occurs in the absence of any chemical effector., ${ }^{3,17,61}$ Fluid shear stress alters the conformation of VWF so that the binding and catalysis of ADAMTS13 takes place at the VWF A2 domain. ${ }^{62}$ High shear stress causes microand macro-conformational changes in VWF. ${ }^{63}$ These hydrodynamic forces cause conformational changes in VWF that expose a binding site in the A1 domain for the platelet glycoprotein $\mathrm{Ib}$ (GPIb) molecule, ${ }^{64}$ facilitating the process of platelet adhesion to the subendothelium. It has to be noted that, once secreted by endothelial cells, UL-VWF is trimmed by ADAMTS13, with production of smaller VWF fragments In the absence of ADAMTS13 activity, either due to genetic mutations or formation of antiADAMTS13 autoantibodies, a life-threatening disease, referred to as thrombotic thrombocytopenic purpura (TTP), does occur causing an uncontrolled microvascular thrombosis (see below) ${ }^{65}$ The unique requirement of shear forces, which permit the cleavage by ADAMTS13 of the Tyr1605-Met1606 peptide bond, finely regulates ADAMTS13 activity and impedes an uncontrolled VWF proteolysis from taking place. Moreover, the VWF-cleaving activity may be positively or negatively modulated by the other structural elements of VWF: ${ }^{66}$ heparin sulfate, platelet GPIb $\alpha$, sodium chloride $^{60}$ and inflammatory cytokines. ${ }^{67}$ Other factors may influence ADAMTS13 and VWF interactions, such as inflammatory cytokines ${ }^{67}$ and hemolysis products. ${ }^{68}$ It cannot be ignored that several Authors have shown that leukocyte proteases such as cathepsin G, elastase, proteinase 3 and MMP9 are able to hydrolyze VWF near or even at the same site where ADAMTS13 proteolyzes the VWF molecule in the A2 domain. ${ }^{69}$ Interestingly, while oxidative modification of VWF Met1606 strongly inhibits proteolysis by ADAMTS13, ${ }^{70,71}$ it may even accelerate the cleavage by leukocyte serine proteases. ${ }^{72}$ Recent studies showed the potential of leukocyte zincand serine proteases present in thrombi to inhibit the adhesion of VWF to platelets under high shear stress and proved that this phenomenon strictly depends on VWF proteolysis. ${ }^{73}$ This alternative control of VWF function is likely linked to local compartments in blood clots, where the serine proteases are relatively protected against their abundant plasma inhibitors, such as $\alpha 2$-macroglobulin and antithrombin.

ADAMTS13 and its Role in the Pathogenesis of Thrombotic Microangiopathy, a Pleiomorphic Clinical Setting. Thrombotic macroangiopathies (TMAs) refer to the disorder of diffuse microvascular thrombosis involving the capillary and arteriolary bed of the brain, kidney and other organs. The patients typically present with 1) severe thrombocytopenia $(<50,000 \mathrm{plts} / \mu \mathrm{l}), 2)$ non-immune hemolysis with presence of schistocytes on blood smears and 3) variable neurologic abnormalities reaching even coma and/or acute renal failure. ${ }^{74}$ Thrombocytopenia results from peripheral consumption of platelets in the microvasculature, whereas erythrocyte fragmentation and hemolysis stem from mechanical injury induced by passage of erythrocytes through platelet thrombi under abnormally high shear stress in the microvasculature (Figure 4). TMAs area group of severe clinical settings that, without treatment, undertake a rapid worsening and death in most cases. Plasma exchange or infusion is the mainstay of treatment for most TMAs. As anticipated above, the pathogenesis of complex syndromes such as TMAs is mostly explicable on the basis of the deficiency of ADAMTS13. However, it should be noted that TMAs are not monogenetic diseases. Thus, the clinical manifestations of this group of disorders are highly variable and heavily affected by the co-existence of other genetic and environmental modifiers. This group of TMAs is constituted by different clinical settings referred to as Thrombotic Thrombocytopenic Purpura (TTP), hemolytic uremic syndrome (HUS), diarrhea-associated HUS or atypical HUS. Unfortunately, any existing clinical or pathological classification of TMAs is based on assumptions that have never been validated. The greatest uncertainty has involved deciding whether 


\section{A) Basal control of VWF multimer size by ADAMTS13}

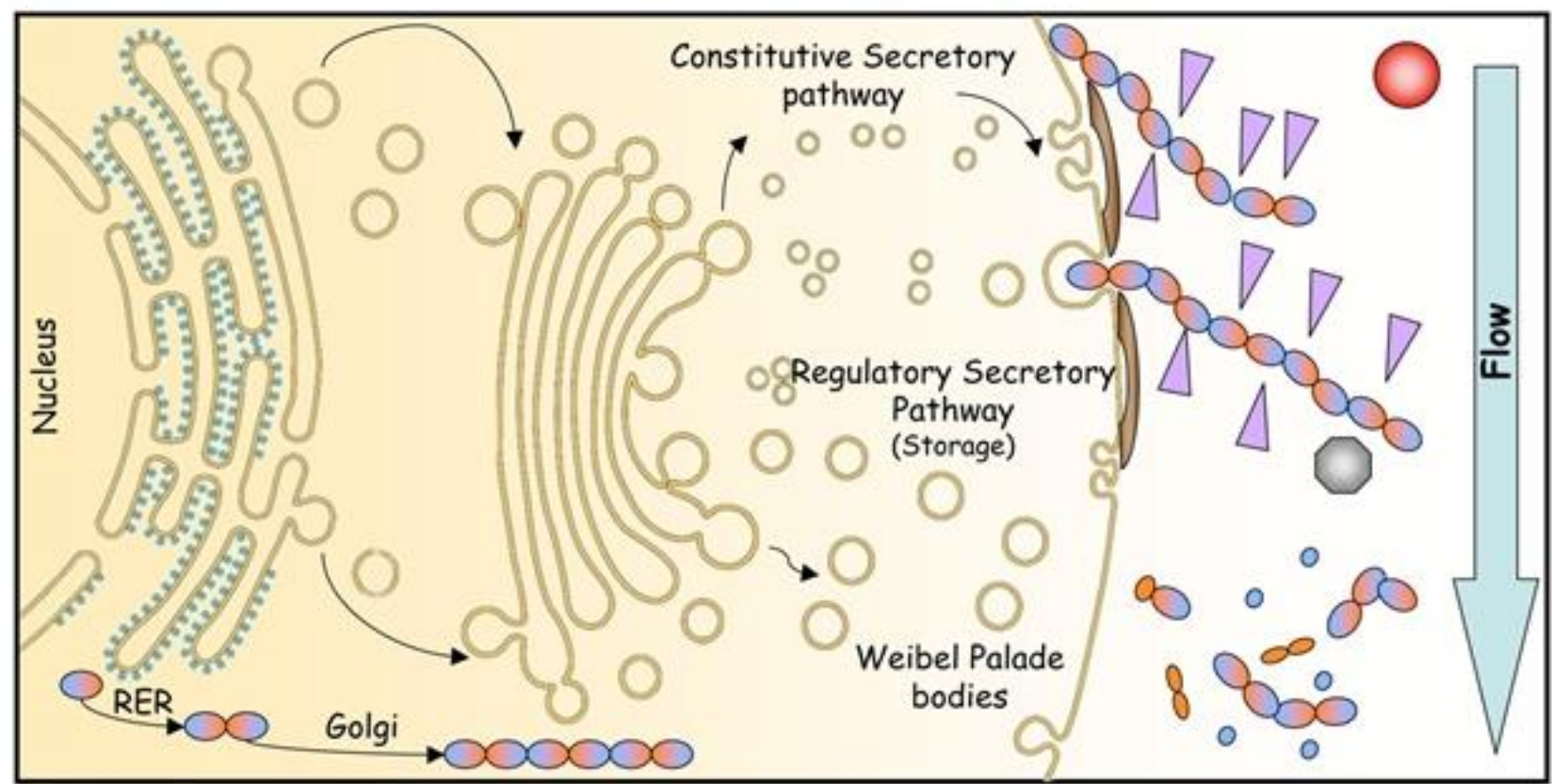

VWF monomer $\bigcirc$ dimer $\infty 0000$ multimers $\nabla$ aDAMTS13 Platelets

$\longrightarrow$ P-selectin $\bigcirc$ Red blood cells

\section{B) Pathological conditions: ADAMTS13 deficiency}

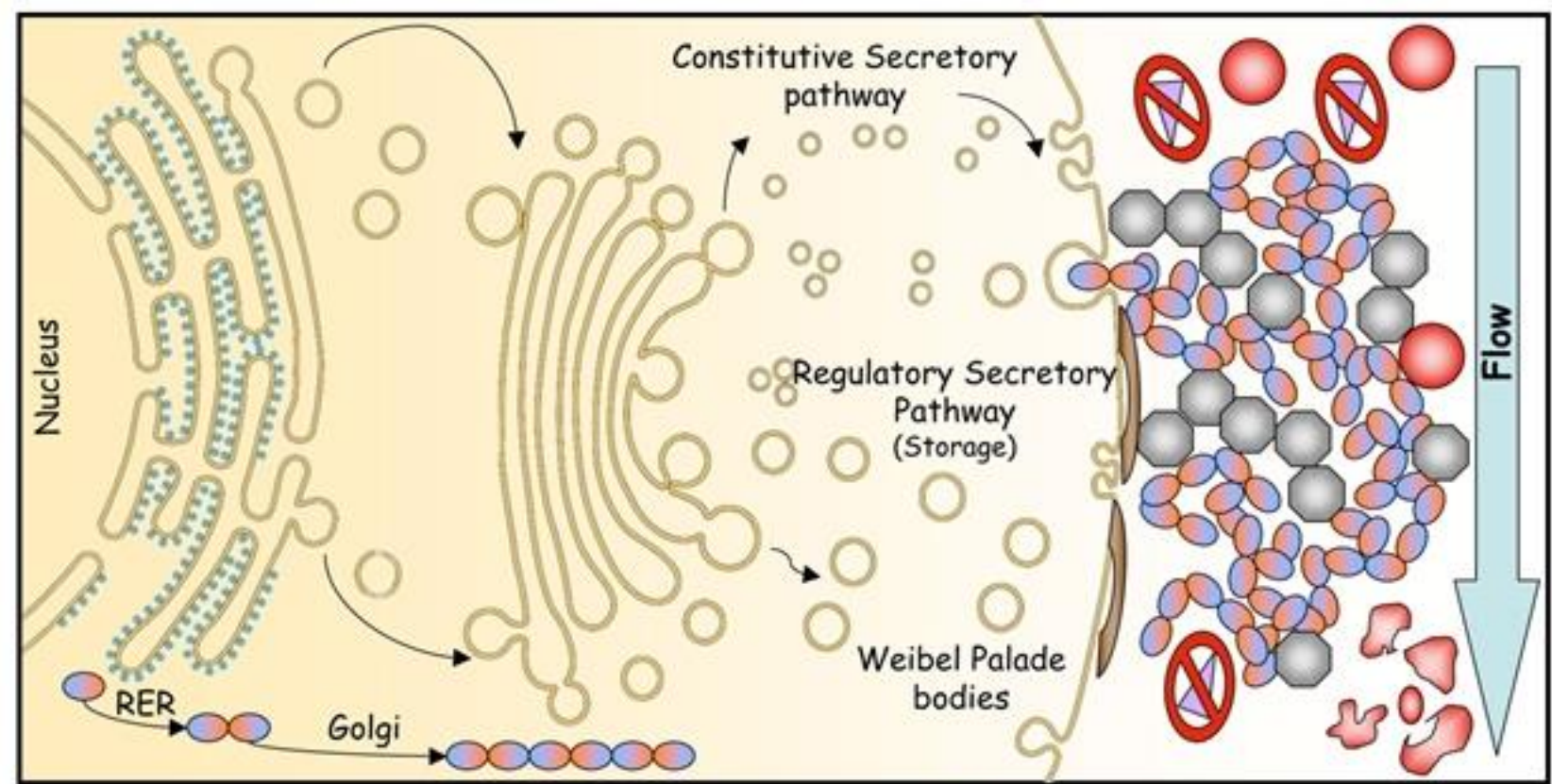

OVWF monomer 00 dimer 00000 multimers $\nabla_{\text {ADAMTS13 }}$ Platelets

\section{P-selectin \\ Red blood cells

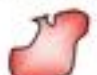 \\ Schistocytes}

Figure 4. Pathogenesis of TMA caused by ADAMTS13 deficiency. A) Von Willebrand factor (VWF) multimers, produced and stored in the Weibel-Palade bodies of the endothelial cells, are secreted and adhere to endothelial cell membranes via GpIb $\alpha$ and P-selectin. Platelets adhere to VWF multimers through platelet membrane glycoprotein GPIb $\alpha$. In flowing blood under high shear stress, VWF in the plateletrich thrombus is in a stretched conformation and is trimmed by ADAMTS13, which limits thrombus growth. B) If ADAMTS13 is absent or inhibited by autoantibodies, VWF-dependent platelet accumulation is uncontrolled and may cause microvascular thrombosis, formation of schistocytes and, ultimately, TMA. 
certain cases represent examples of TTP or HUS. A rule of thumb has suggested that HUS may usually be distinguished from TTP because HUS occurs predominantly in individuals younger than 10 years, while TTP occurs predominantly in adults. However, this differentiation is not reliable, as either condition can occur in either group. Other clinical features aid in distinguishing the conditions at any age of onset. For instance, renal manifestations are usually more prominent in HUS than neurological ones, whereas neurological manifestations are usually more prominent in TTP than renal ones. Fever precedes TTP more commonly than it precedes HUS. ${ }^{75}$ Despite these distinctions, continued recognition of borderline or atypical cases has generated doubts about the possibility that objective criteria other than age are able to distinguish "atypical" HUS from "atypical" TTP. This problem led to the application of the unsatisfactory term TTP-HUS to mean an indistinctly defined and clinically heterogenous collection of cases between classic TTP and classic HUS. The recognition of phenotypic instability in recurrent cases encouraged use of this term. For example, 1 patient had 5 episodes manifesting the HUS phenotype before the age of 15 years and 9 episodes manifesting the TTP phenotype after 20 years of age. ${ }^{76}$

It should be noted that TTP and HUS share the fundamental pathologic feature of arteriolar thrombosis with vessel wall intimal swelling and fibrinoid necrosis. However, the composition of the thrombi differs histopathologically, at least in well-defined cases of TTP and HUS. Those of such well-defined TTP cases contain degranulated platelets and von Willebrand factor. Those of Shiga toxin-provoked HUS are rich in fibrin and thus arise from activation of the plasma coagulation cascade. ${ }^{4}$

Fortunately, recent advances in understanding the pathogenesis of TTP somewhat clarified the boundaries between microangiopathic disorders with renal or neurological manifestations, and they have produced useful diagnostic tests for some forms of clinically defined TTP.

A) Relationship Between ADAMTS13 and Occurrence of TMAs. Investigations have demonstrated a high degree of relevance in the relationship of ADAMTS13 to TTP. These investigations defined a heritable form of TTP with severe $(<5 \%)$ ADAMTS13 activity deficiency and an acquired form due to the elaboration of antibodies directed at 1 or more ADAMTS13 epitopes. $^{77}$

However, many thrombotic microangiopathies (TMAs) are not associated either with severe ADAMTS13 activity deficiency or with antibodies that block ADAMTS13 activity. This class of patients may represent $>30 \%$ of all TMA patients. ${ }^{16}$ In some instances, the clinical syndrome is indistinguishable from typical TTP. At autopsy, widespread hyaline thrombi, accompanied by variable fibroblastic infiltration and endothelial overlay, are found in the terminal arterioles and capillaries of multiple organs. The thrombi are found most extensively in the heart, brain, kidney, pancreas, spleen, mesentery and adrenal gland, and are composed primarily of platelets and von Willebrand factor. ${ }^{78-80}$ A small amount of fibrin may be present surrounding the amorphous or granular materials. In older lesions, hyaline deposits may be seen in the sub-endothelial layers of capillaries and between the endothelium and muscular layers of arterioles. Pre-occlusive pseudoaneurysmal dilatation may also be present. Fibrinoid necrosis and vascular or perivascular inflammatory cell infiltration are characteristically absent or minimal. Some cases, especially those in adults, are associated with promoting factors that are associated with the development of typical hereditary or acquired TTP. Recent schemes have used the identification of such promoting factors to classify TTP-like thrombotic disorders without severe or acquired abnormalities of ADAMTS13 function, as just defined. These entities tend to occur in adults and sometimes manifest features that occur along a clinical spectrum between TTP and HUS. Many of these illnesses cannot be distinguished by using currently available laboratory tests, except when the underlying etiologic illnesses are symptomatic. These conditions share with TTP and HUS the fundamental finding of thrombocytopenic and hemolytic TMA on peripheral blood smear. In the following paragraphs, we will treat only the ADAMTS13-related forms of TMAs/TTP. These syndromes include: 1) the congenital and 2) acquired deficiency of the metalloprotease. Finally, we will mention a recently discovered pathogenetic mechansisms that can be responsible for accumulation of UL-VWF multimers and promote forms of TMAs in cardiovascular and metabolic disorders by perturbing the VWF/ADAMTS13 interaction.

B) Congenital ADAMTS13 Deficiency. Many studies in different ethnic populations have demonstrated the presence of ADAMTS13 mutations in patients with TTP. ${ }^{16,26,48,68,81-106}$ Some aspects emerging from studies of ADAMTS13 congenital deficiency in mice could help to unravel the role of ADAMTS13 and UL-VWF multimers in the pathogenesis of TMAs. For instance, inactivation of the ADAMTS13 gene in mice failed to generate the phenotype of TTP microvascular thrombosis until the ADAMTS13 null allele was transferred to a particular mouse strain, CASA/Rk, that has increased levels of VWF. ${ }^{107,108}$ Nevertheless, crossbreeding studies showed that the development of TTP is independent of mouse plasma VWF levels. In 
CASA/Rk mice with homozygous ADAMTS13 null alleles, spontaneous thrombosis and death occur in post-neonatal life. ${ }^{107}$ Only administration of shiga toxin is able to induce a massive secretion of UL-VWF multimers from endothelial cells. ${ }^{109}$ From a clinical standpoint, there is no evidence of antecedent shiga toxin exposure in patients of TTP. Only a small fraction of TTP patients has elevated plasma VWF levels. Thus, the relevance of the shiga toxinADAMTS13-deficient mouse model to either TTP or shiga toxin-associated HUS remains uncertain. We can only speculate that the lack of a thrombotic phenotype in some mouse strains with severe deficiency of ADAMTS13 due to its gene inactivation suggests in these strains the presence of modifiers that affect the response of VWF to shear stress. To date, about 80 mutations responsible for hereditary TTP have been identified in the ADAMTS13 gene. ${ }^{16,26,48,68,81-106}$ Seven are splice mutations, ten frameshift deletions, four frameshift insertions, eleven nonsense mutations and the remaining 45 mutations lead to codon changes. Moreover, numerous Single Nucleotide Polymorphisms (SNPs) have been recognized in recent years: eight of these SNPs are expressed and affect expression, secretion and activity of the enzyme, whereas eighteen are silent. The mutated sites in ADAMTS13 are distributed across many exons and

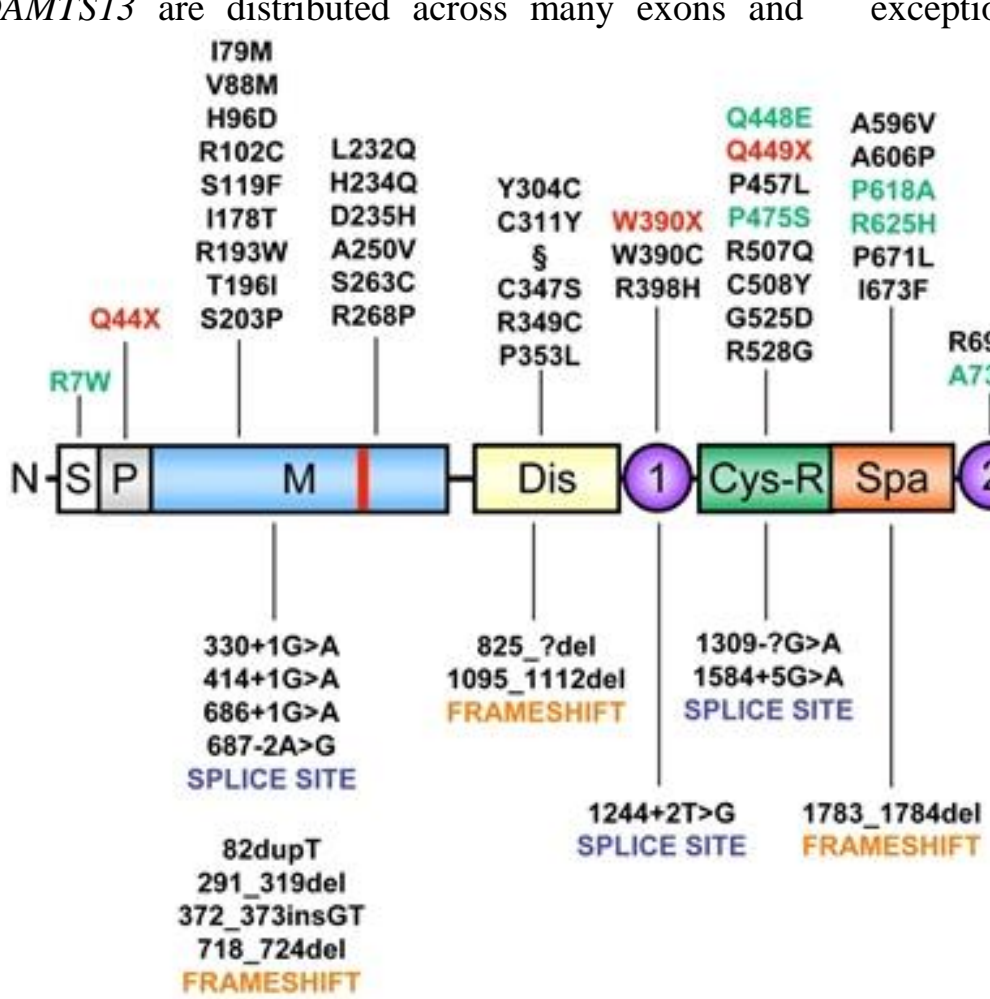

introns throughout the gene. The absence of clusters ("hot-spots") of mutations within the metalloprotease domain implies structural and functional importance of other regions besides the catalytic site. This finding is in-line with the observed relevance of exosites in ADAMTS13 in the molecular recognition and proteolytic processing of $\mathrm{VWF}^{49,64,110}$ under both static and high shear rate conditions (see above). In patients with hereditary TTP, homozygous or compound heterozygous mutations of the ADAMTS13 gene lead to severe ADAMTS13 deficiency. Globally, the affected residues span the entire spectrum of the ADAMTS13 gene. Figure $\mathbf{5}$ shows the principal mutations discovered along the ADAMTS13 gene. Mutations of the ADAMTS13 gene may cause impaired protein synthesis, secretion or proteolytic activity, depending on its localization, as determined in numerous sitedirected mutagenesis and expression studies. Heterozygous individuals have ADAMTS13 activity at $40-70 \%$ of normal values, while a TTP phenotype is present in more than $90 \%$ of the patients with double heterozygous or homozygous mutations. However, it may be predicted that variable phenotypic severity of TTP may arise from the various ADAMTS13 mutations. ${ }^{111}$ Only a few mutations have been described in more than one pedigree. A notable exception is 4143dupA, which has been described in

Figure 5. Linear map of the location of ADAMTS13 mutations found in patients with congenital thrombotic thrombocytopenic purpura (TTP) [Upshaw-Schulman syndrome (USS)]. The missense mutations, nonsense mutations (red) and single nucleotide polymorphisms (SNPs) (green) are shown above the domain structure of ADAMTS13. The mutations that result in alternative splicing of ADAMTS13 mRNA or frameshifts are listed under the domain structure of ADAMTS13. S indicates the signal peptide; P, propeptide; M, metalloprotease (location of zinc-binding motif shown in red); Dis, disintegrin domain; 1, first thrombospondin type 1 (TSP1) repeat; Cys-R, cysteine-rich domain; Spa, spacer domain; 2 through 8, the second to eighth TSP1 repeats; C1 and C2, two CUB domains (for complement C1r/C1s, Uegf, Bmp1 domain) §p.[C322G (+) T323R (+) F324L]. 
multiple pedigrees of Northern and Central Europe and in Turkey. Haplotype analysis suggests that many, if not all, of the 4143dupA mutant alleles probably originated from a common ancestry. ${ }^{87}$ Why this particular allele is much more frequent than other mutant alleles remains an unanswered question. Other ethnical characteristics concern one ADAMTS13 variant allele, 1423C $>\mathrm{T}$ (P475S), found in Japanese $(5.1 \%)$, Koreans $(4 \%)$ and Chinese $(0.5-1.7 \%)$ but not detected among Caucasians or African Americans. ${ }^{26,112}$ This polymorphism had raised considerable interest because in expression studies this mutation markedly reduces the activity of ADAMTS13 to approximately $10 \%$ of control, raising the possibility that partial deficiency of ADAMTS13 deficiency may be quite common among Northeast Asians. Nevertheless, this prediction was not correct, as more recent investigations have shown that carriers of the P475S polymorphism have only a minor decrease $(10 \%)$ of the ADAMTS13 activity and revealed that the previously reported low activity of the P475S variant resulted from the effect of high urea concentration used in the ADAMTS13 activity assay. ${ }^{113}$ Thus, this mutant might have only an abnormal stability. Recently, a novel mutation causing a severe ADAMTS13 deficiency, p.E735X, has been detected in a 2 year old Tunisian child presented with chronic thrombocytopenic purpura, which failed to respond to corticosteroids. ${ }^{114}$

C) Inhibitors of ADAMTS13. A strong deficiency of ADAMTS13 activity can also be associated to development of auto-antibodies against the protease. The formation of $\operatorname{IgG}$ or IgM anti-ADAMTS13 antibodies may be responsible for the onset of TMAs idiopathic or secondary to drugs, pregnancy or diseases such as infections, cancers and autoimmune diseases. ${ }^{21,115}$ In patients with acquired TTP, deficiency of ADAMTS13 results from autoimmune inhibitors of ADAMTS13, which either inhibit its catalytic activity or induce a rapid clearance from the circulation. ${ }^{16,116-121}$ Similar to other autoimmune disorders, the etiologies of acquired TTP are unknown and TTP patients often exhibit positive autoimmune reactions to different target antigens [], ${ }^{117}$ suggesting that defective immune regulation may contribute to the development of TTP. A defective regulation of T-reg and tolerogenic dendritic cells may be responsible for the occurrence of anti-ADAMTS13 antibodies, in analogy with what has been shown in other autoimmune coagulation inhibitors, such as anti-FVIII antibodies. ${ }^{122}$ HIV infection may also be a risk factor for TTP, although this association has not been confirmed by all Authors. ${ }^{123}$ The inhibitors are more frequently $\mathrm{IgG}$, although occasional production of $\operatorname{IgA}$ and $\operatorname{IgM}$ antibodies has been described. In a recent study, $\operatorname{IgG}(4)$ was found to be the most prevalent IgG subclass (90\%) in 58 patients with acquired TTP, followed by $\operatorname{IgG}(1)$ $(52 \%), \operatorname{IgG}(2)(50 \%)$ and $\operatorname{IgG}(3)(33 \%) .{ }^{124}$ These studies also showed that $\operatorname{IgG}(4)$ may be found either alone $(33 \%)$ or with other IgG subclasses $(67 \%){ }^{124}$ $\mathrm{IgG}(4)$ was not detected in $10 \%$ of the patients. Patients with high $\operatorname{IgG}(4)$ levels and undetectable $\operatorname{IgG}(1)$ are more prone to relapse than patients with low IgG(4) levels and detectable IgG(1) []. ${ }^{124}$ Remarkably, a rising ADAMTS13 inhibitor level may be associated with switching of the IgG subclasses, suggesting that cytokine dysregulation may be responsible for the rising inhibitor levels observed in some cases of TTP. ${ }^{125}$ Epitope mapping studies showed that the spacer domain, ${ }^{33,50,126}$ specifically residues T572-N579 and V657-G666, ${ }^{33}$ comprise a common antigenic core region that is a relevant target for ADAMTS13 antibodies in TTP. Notably, the proteolytic activity of ADAMTS13 variants truncated upstream of the Cysrich domain is not generally inhibited by the inhibitors of patients with TMAs. These non-inhibited ADAMTS13 recombinant constructs may be used to overcome, at least in part, the difficult management of patients with high inhibitor levels. The levels of the ADAMTS13 inhibitors tend to be low $(<10 \mathrm{U} / \mathrm{mL}),{ }^{118,127}$ often receding to even lower or undetectable levels within weeks or months. Such characteristics of the ADAMTS13 inhibitors suggest that the immune response is induced by exposure to exogenous antigens with molecular mimicry to ADAMTS13. The level of anti-ADAMTS13 inhibitors determines the efficacy of therapeutic strategies, particularly plasma exchange, aimed at eliminating their pathologic effects. Usually, ADAMTS13 inhibitors, measured by the Bethesda assay in clinical laboratories ${ }^{128}$ have low titers $(<10$ Bethesda units $/ \mathrm{ml})$ and self-limited course. However, if the level of antiADAMTS13 inhibitors is high, the treatment may fail. ${ }^{125}$ Moreover, refractory TMA forms, characterized by persistent anti-ADAMTS13 inhibitors, have also been reported in patients requiring long-term plasma exchange treatment and immunosuppressive therapy with rituximab. ${ }^{129}$

The Role of VWF-ADAMTS13 Interaction in Other Arterial Thrombotic Diseases. It has been suggested that VWF plays an important role in the pathogenesis of arterial thrombotic disorders. Previous studies have shown the relevance of platelets and VWF in the initiation of atherosclerotic plaque formation. Both inactivation of VWF and inhibition of VWF-GP1b interaction delay the formation of fatty streaks VWF. From a biological standpoint, it is likely that VWF contributes to the pathogenesis of early atherosclerotic lesions. Hence, many studies have investigated the 
association between VWF plasma levels and the subsequent risk of cardiovascular disease. In the ARIC study, the relative risk (RR) for coronary artery disease (CHD) for the highest vs. the lowest tertiles of VWF levels was approximately 1.3. ${ }^{130,131}$ Moreover, VWF was found to play a relevant role in thrombotic microangiopathies occurring in diabetes mellitus. ${ }^{132}$ More recently, compelling evidence has emerged about the association of high VWF levels with occurrence of ischemic stroke, particularly in the cardioembolic and cryptogenetic subtypes. ${ }^{133,134}$ Recently a relative inhibition of VWF-ADAMTS13 interaction linked to oxidative modification of VWF in some clinical settings such as diabetes mellitus and end stage renal disease has been shown to be strongly associated to enhanced incidence of thrombotic macro- and microangiopathies. ${ }^{71,135,136}$

Future Directions. After the discovery that normal plasma contains a zinc protease able to specifically

\section{References:}

1. Moake JL, Rudy CK, Troll JH, Weinstein MJ, Colannino NM, Azocar J, Seder RH, Hong SL, Deykin D. Unusually large plasma factor VIII:von Willebrand factor multimers in chronic relapsing thrombotic thrombocytopenic purpura. N Engl J Med. 1982; 307: 1432-5

http://dx.doi.org/10.1056/NEJM198212023072306 PMid:6813740

2. Furlan M, Robles R, Lamie B. Partial purification and characterization of a protease from human plasma cleaving von Willebrand factor to fragments produced by in vivo proteolysis. Blood. 1996; 87: 4223-34. PMid:8639781

3. Tsai HM. Physiologic cleavage of von Willebrand factor by a plasma protease is dependent on its conformation and requires calcium ion. Blood. 1996; 87: 4235-44. PMid:8639782

4. Fujikawa K, Suzuki H, McMullen B, Chung D. Purification of human von Willebrand factor-cleaving protease and its identification as a new member of the metalloproteinase family. Blood. 2001; 98: 1662-6.

http://dx.doi.org/10.1182/blood.V98.6.1662 PMid:11535495

5. Gerritsen HE, Robles R, Lammle B, Furlan M. Partial amino acid sequence of purified von Willebrand factor-cleaving protease. Blood. 2001; 98: 1654-61 http://dx.doi.org/10.1182/blood.V98.6.1654 PMid:11535494

6. Levy GG, Nichols WC, Lian EC, Foroud T, McClintick JN, McGee BM, Yang AY, Siemieniak DR, Stark KR, Gruppo R, Sarode R, Shurin SB, Chandrasekaran V, Stabler SP, Sabio H, Bouhassira EE, Upshaw JD, Jr., Ginsburg D, Tsai HM. Mutations in a member of the ADAMTS gene family cause thrombotic thrombocytopenic purpura. Nature. 2001; 413: 48894. http://dx.doi.org/10.1038/35097008 PMid:11586351

7. Soejima K, Mimura N, Hirashima M, Maeda H, Hamamoto T, Nakagaki T, Nozaki C. A novel human metalloprotease synthesized in the liver and secreted into the blood: possibly, the von Willebrand factor-cleaving protease? J Biochem. 2001; 130: 475-80.

http://dx.doi.org/10.1093/oxfordjournals.jbchem.a003009 PMid:11574066

8. Zheng X, Chung D, Takayama TK, Majerus EM, Sadler JE, Fujikawa K. Structure of von Willebrand factor-cleaving protease (ADAMTS13), a metalloprotease involved in thrombotic thrombocytopenic purpura. J Biol Chem. 2001; 276: 41059-63. $\quad$ http://dx.doi.org/10.1074/jbc.C100515200 PMid: 11557746

9. Tsai HM. Von Willebrand factor, ADAMTS13, and thrombotic thrombocytopenic purpura. J Mol Med. 2002; 80: 639-47. proteolyze VWF, the past decade has witnessed the most exciting advances in the history of studies on the pathogenesis of TMAs. However, many issues still need to be addressed. The knowledge of some mechanistic aspects of ADAMTS13 catalysis and its regulation, the development of sensitive and reliable assays in the clinical diagnostics of TMAs and the nature of modifiers of ADAMTS13 activity on VWF multimers in patients affected by TMAs require further improvement. From a biotechnological standpoint, industrial production of partially deleted ADAMTS13, non-suppressible by pathological auto-antibodies, may circumvent the difficulties that replacement therapies with recombinant full-length ADAMTS13 may encounter in patients with acquired TTP. Finally, basic research to clarify the immunological mechanisms of generation of ADAMTS13 inhibitors ${ }^{137}$ will aid in the discovery of new strategies able to improve the prevention, diagnosis and management of TMAs.

http://dx.doi.org/10.1007/s00109-002-0369-8 PMid:12395148

10. Sadler JE. Biochemistry and genetics of von Willebrand factor. Annu Rev Biochem. 1998; 67: 395-424. http://dx.doi.org/10.1146/annurev.biochem.67.1.395 PMid:9759493

11. Wagner DD, Marder VJ. Biosynthesis of von Willebrand protein by human endothelial cells. Identification of a large precursor polypeptide chain. J Biol Chem. 1983; 258: 2065-7. PMid:6600453

12. Ruggeri ZM, Zimmerman TS. The complex multimeric composition of factor VIII/von Willebrand factor. Blood. 1981; 57: 1140-3. PMid:6784794

13. Tsai HM, Nagel RL, Hatcher VB, Sussman, II. Multimeric composition of endothelial cell-derived von Willebrand factor. Blood. 1989; 73: 2074-6. PMid:2786433

14. Padilla A, Moake JL, Bernardo A, Ball C, Wang Y, Arya M, Nolasco L, Turner N, Berndt MC, Anvari B, Lopez JA, Dong JF P-selectin anchors newly released ultralarge von Willebrand factor multimers to the endothelial cell surface. Blood. 2004; 103: 2150-6. http://dx.doi.org/10.1182/blood-2003-08-2956 PMid:14630802

15. Sadler JE. von Willebrand factor. J Biol Chem. 1991; 266: 22777-80. PMid:1744071

16. Scaglione GL, Lancellotti S, Pap M, De Spirito M, Maiorana A, Baronciani L, Pagliari MT, Arcovito A, Di Stasio E, Peyvandi F, De Cristofaro R. The Type 2b P.R1306w Natural Mutation Of Von Willebrand Factor Dramatically Enhances The Multimer Sensitivity To Shear Stress. J Thromb Haemost. 2013. http://dx.doi.org/10.1111/jth.12346

17. Tsai HM, Sussman, II, Nagel RL. Shear stress enhances the proteolysis of von Willebrand factor in normal plasma. Blood. 1994; 83: 2171-9. PMid:8161783

18. Di Stasio E, Romitelli F, Lancellotti S, Arcovito A, Giardina B, De Cristofaro R. Kinetic study of von Willebrand factor selfaggregation induced by ristocetin. Biophys Chem. 2009; 144: 101-7. http://dx.doi.org/10.1016/j.bpc.2009.07.002 PMid:19647361

19. Di Stasio E, De Cristofaro R. The effect of shear stress on protein conformation: Physical forces operating on biochemical systems: The case of von Willebrand factor. Biophys Chem. 2010; 153: 1-8. http://dx.doi.org/10.1016/j.bpc.2010.07.002 PMid:20797815

20. Lopez JA, Dong JF. Cleavage of von Willebrand factor by ADAMTS-13 on endothelial cells. Semin Hematol. 2004; 41: 15-23. http://dx.doi.org/10.1053/j.seminhematol.2003.10.004 
21. Furlan M, Robles R, Galbusera M, Remuzzi G, Kyrle PA, Brenner B, Krause M, Scharrer I, Aumann V, Mittler U, Solenthaler M, Lammle B. von Willebrand factor-cleaving protease in thrombotic thrombocytopenic purpura and the hemolytic-uremic syndrome. N Engl J Med. 1998; 339: 1578-84. http://dx.doi.org/10.1056/NEJM199811263392202 PMid:9828245

22. Tsai HM, Lian EC. Antibodies to von Willebrand factorcleaving protease in acute thrombotic thrombocytopenic purpura. N Engl J Med. 1998; 339: 1585-94. http://dx.doi.org/10.1056/NEJM199811263392203 PMid:9828246 PMCid:PMC3159001

23. Hulstein JJ, de Groot PG, Silence K, Veyradier A, Fijnheer R, Lenting PJ. A novel nanobody that detects the gain-of-function phenotype of von Willebrand factor in ADAMTS13 deficiency and von Willebrand disease type 2B. Blood. 2005; 106: 3035-42. http://dx.doi.org/10.1182/blood-2005-03-1153 PMid:16014562

24. Chung DW, Fujikawa K. Processing of von Willebrand factor by ADAMTS-13. Biochemistry. 2002; 41: 11065-70. http://dx.doi.org/10.1021/bi0204692

25. Plaimauer B, Zimmermann $\mathrm{K}$, Volkel D, Antoine G, Kerschbaumer R, Jenab P, Furlan M, Gerritsen H, Lammle B, Schwarz HP, Scheiflinger F. Cloning, expression, and functional characterization of the von Willebrand factor-cleaving protease (ADAMTS13). Blood. 2002; 100: 3626-32 http://dx.doi.org/10.1182/blood-2002-05-1397 PMid:12393399

26. Kokame K, Matsumoto M, Soejima K, Yagi H, Ishizashi H, Funato M, Tamai H, Konno M, Kamide K, Kawano Y, Miyata $\mathrm{T}$, Fujimura Y. Mutations and common polymorphisms in ADAMTS13 gene responsible for von Willebrand factorcleaving protease activity. Proc Natl Acad Sci U S A. 2002; 99: 11902-7. http://dx.doi.org/10.1073/pnas.172277399 PMid:12181489 PMCid:PMC129366

27. Shang D, Zheng XW, Niiya M, Zheng XL. Apical sorting of ADAMTS13 in vascular endothelial cells and Madin-Darby canine kidney cells depends on the CUB domains and their association with lipid rafts. Blood. 2006; 108: 2207-15 http://dx.doi.org/10.1182/blood-2006-02-002139 PMid:16597588 PMCid:PMC1895558

28. Turner N, Nolasco L, Tao Z, Dong JF, Moake J. Human endothelial cells synthesize and release ADAMTS-13. J Thromb Haemost. 2006; 4: 1396-404. http://dx.doi.org/10.1111/j.15387836.2006.01959.x PMid:16706987

29. Tati R, Kristoffersson AC, Stahl AL, Morgelin M, Motto D, Satchell S, Mathieson P, Manea-Hedstrom M, Karpman D. Phenotypic expression of ADAMTS13 in glomerular endothelial cells. PLoS One. 2011; 6: e21587.

http://dx.doi.org/10.1371/journal.pone.0021587 PMid:21720563 PMCid:PMC3123364

30. Liu L, Choi H, Bernardo A, Bergeron AL, Nolasco L, Ruan C, Moake JL, Dong JF. Platelet-derived VWF-cleaving metalloprotease ADAMTS-13. J Thromb Haemost. 2005; 3: 2536-44. http://dx.doi.org/10.1111/j.1538-7836.2005.01561.x PMid:16176307

31. Suzuki M, Murata M, Matsubara Y, Uchida T, Ishihara H, Shibano T, Ashida S, Soejima K, Okada Y, Ikeda Y. Detection of von Willebrand factor-cleaving protease (ADAMTS-13) in human platelets. Biochem Biophys Res Commun. 2004; 313 : 212-6. http://dx.doi.org/10.1016/j.bbrc.2003.11.111 PMid:14672719

32. Soejima K, Nakamura H, Hirashima M, Morikawa W, Nozaki C, Nakagaki T. Analysis on the molecular species and concentration of circulating ADAMTS13 in Blood. J Biochem. 2006; 139: 147-54. http://dx.doi.org/10.1093/jb/mvj013 PMid:16428330

33. Crawley JT, de Groot R, Xiang Y, Luken BM, Lane DA. Unraveling the scissile bond: how ADAMTS13 recognizes and cleaves von Willebrand factor. Blood. 2011; 118: 3212-21. http://dx.doi.org/10.1182/blood-2011-02-306597 PMid:21715306 PMCid:PMC3179391

34. Ono T, Mimuro J, Madoiwa S, Soejima K, Kashiwakura Y, Ishiwata A, Takano K, Ohmori T, Sakata Y. Severe secondary deficiency of von Willebrand factor-cleaving protease (ADAMTS13) in patients with sepsis-induced disseminated intravascular coagulation: its correlation with development of renal failure. Blood. 2006; 107: 528-34. http://dx.doi.org/10.1182/blood-2005-03-1087 PMid:16189276

35. Uemura M, Tatsumi K, Matsumoto M, Fujimoto M, Matsuyama T, Ishikawa M, Iwamoto TA, Mori T, Wanaka A, Fukui $\mathrm{H}$, Fujimura Y. Localization of ADAMTS13 to the stellate cells of human liver. Blood. 2005; 106: 922-4. http://dx.doi.org/10.1182/blood-2005-01-0152 PMid:15855280

36. Zhou W, Inada M, Lee TP, Benten D, Lyubsky S, Bouhassira EE, Gupta S, Tsai HM. ADAMTS13 is expressed in hepatic stellate cells. Lab Invest. 2005; 85: 780-8. http://dx.doi.org/10.1038/labinvest.3700275 PMid:15806136 PMCid:PMC2573995

37. Niiya M, Uemura $M$, Zheng XW, Pollak ES, Dockal M, Scheiflinger F, Wells RG, Zheng XL. Increased ADAMTS-13 proteolytic activity in rat hepatic stellate cells upon activation in vitro and in vivo. J Thromb Haemost. 2006; 4: 1063-70. http://dx.doi.org/10.1111/j.1538-7836.2006.01893.x PMid:16689760 PMCid:PMC2577223

38. Cal S, Obaya AJ, Llamazares M, Garabaya C, Quesada V, Lopez-Otin C. Cloning, expression analysis, and structural characterization of seven novel human ADAMTSs, a family of metalloproteinases with disintegrin and thrombospondin-1 domains. Gene. 2002; 283: 49-62. http://dx.doi.org/10.1016/S0378-1119(01)00861-7

39. Bork P, Beckmann G. The CUB domain. A widespread module in developmentally regulated proteins. J Mol Biol. 1993; 231: 539-45. http://dx.doi.org/10.1006/jmbi.1993.1305 PMid:8510165

40. Colige A, Sieron AL, Li SW, Schwarze U, Petty E, Wertelecki W, Wilcox W, Krakow D, Cohn DH, Reardon W, Byers PH, Lapiere CM, Prockop DJ, Nusgens BV. Human Ehlers-Danlos syndrome type VII $\mathrm{C}$ and bovine dermatosparaxis are caused by mutations in the procollagen I N-proteinase gene. Am J Hum Genet. 1999; 65: 308-17. http://dx.doi.org/10.1086/302504 PMid:10417273 PMCid:PMC1377929

41. Dagoneau N, Benoist-Lasselin C, Huber C, Faivre L, Megarbane A, Alswaid A, Dollfus H, Alembik Y, Munnich A, LegeaiMallet L, Cormier-Daire V. ADAMTS10 mutations in autosomal recessive Weill-Marchesani syndrome. Am J Hum Genet. 2004; 75: 801-6. http://dx.doi.org/10.1086/425231 PMid:15368195 PMCid:PMC1182109

42. Hurskainen TL, Hirohata S, Seldin MF, Apte SS. ADAM-TS5, ADAM-TS6, and ADAM-TS7, novel members of a new family of zinc metalloproteases. General features and genomic distribution of the ADAM-TS family. J Biol Chem. 1999; 274: 25555-63. PMid: 10464288

43. Shindo T, Kurihara H, Kuno K, Yokoyama H, Wada T, Kurihara Y, Imai T, Wang Y, Ogata M, Nishimatsu H, Moriyama N, Ohhashi Y, Morita H, Ishikawa T, Nagai R, Yazaki Y, Matsushima K. ADAMTS-1: a metalloproteinase-disintegrin essential for normal growth, fertility, and organ morphology and function. $\mathrm{J}$ Clin Invest. 2000; 105: 1345-52. http://dx.doi.org/10.1172/JCI8635 PMCid:PMC315464

44. Tortorella MD, Burn TC, Pratta MA, Abbaszade I, Hollis JM, Liu R, Rosenfeld SA, Copeland RA, Decicco CP, Wynn R, Rockwell A, Yang F, Duke JL, Solomon K, George H, Bruckner R, Nagase H, Itoh Y, Ellis DM, Ross H, Wiswall BH, Murphy K, Hillman MC, Jr., Hollis GF, Newton RC, Magolda RL, Trzaskos JM, Arner EC. Purification and cloning of aggrecanase-1: a member of the ADAMTS family of proteins. Science. 1999; 284: 1664-6. http://dx.doi.org/10.1126/science.284.5420.1664 PMid:10356395

45. Chauhan AK, Kisucka J, Brill A, Walsh MT, Scheiflinger F, Wagner DD. ADAMTS13: a new link between thrombosis and inflammation. J Exp Med. 2008; 205: 2065-74. http://dx.doi.org/10.1084/jem.20080130 PMCid:PMC2526201

46. Akiyama M, Takeda S, Kokame K, Takagi J, Miyata T. Crystal structures of the noncatalytic domains of ADAMTS13 reveal multiple discontinuous exosites for von Willebrand factor. Proc Natl Acad Sci U S A. 2009; 106: 19274-9. http://dx.doi.org/10.1073/pnas.0909755106 PMid:19880749 PMCid:PMC2780749

47. Akiyama M, Nakayama D, Takeda S, Kokame K, Takagi J, 
Miyata T. Crystal structure and enzymatic activity of an ADAMTS13 mutant with the East Asian-specific P475S polymorphism. J Thromb Haemost. 2013.

http://dx.doi.org/10.1111/jth.12279 PMid:23621748

48. Bestetti G, Stellari A, Lattuada A, Corbellino M, Parravicini C, Calzarossa C, Cenzuales S, Moroni M, Galli M, Rossi E. ADAMTS 13 genotype and $\mathrm{vWF}$ protease activity in an Italian family with TTP. Thromb Haemost. 2003; 90: 955-6. PMid:14597993

49. Zheng X, Nishio K, Majerus EM, Sadler JE. Cleavage of von Willebrand factor requires the spacer domain of the metalloprotease ADAMTS13. J Biol Chem. 2003; 278: 3013641. http://dx.doi.org/10.1074/jbc.M305331200 PMid:12791682

50. Klaus C, Plaimauer B, Studt JD, Dorner F, Lammle B, Mannucci PM, Scheiflinger F. Epitope mapping of ADAMTS13 autoantibodies in acquired thrombotic thrombocytopenic purpura. Blood. 2004; 103: 4514-9. http://dx.doi.org/10.1182/blood-2003-12-4165 PMid:14976043

51. Yiallouros I, Grosse Berkhoff E, Stocker W. The roles of Glu93 and Tyr149 in astacin-like zinc peptidases. FEBS Lett. 2000; 484: 224-8. http://dx.doi.org/10.1016/S0014-5793(00)02163-3

52. Bode W, Fernandez-Catalan C, Tschesche H, Grams F, Nagase $\mathrm{H}$, Maskos K. Structural properties of matrix metalloproteinases. Cell Mol Life Sci. 1999; 55: 639-52. http://dx.doi.org/10.1007/s000180050320 PMid:10357232

53. Bode W, Gomis-Ruth FX, Stockler W. Astacins, serralysins, snake venom and matrix metalloproteinases exhibit identical zinc-binding environments (HEXXHXXGXXH and Met-turn) and topologies and should be grouped into a common family, the 'metzincins'. FEBS Lett. 1993; 331: 134-40. http://dx.doi.org/10.1016/0014-5793(93)80312-I

54. Rawlings ND, Barrett AJ. Evolutionary families of metallopeptidases. Methods Enzymol. 1995; 248: 183-228. http://dx.doi.org/10.1016/0076-6879(95)48015-3

55. Stocker W, Grams F, Baumann U, Reinemer P, Gomis-Ruth FX, McKay DB, Bode W. The metzincins--topological and sequential relations between the astacins, adamalysins, serralysins, and matrixins (collagenases) define a superfamily of zinc-peptidases. Protein Sci. 1995; 4: 823-40. http://dx.doi.org/10.1002/pro.5560040502

PMid:7663339 PMCid:PMC2143131

56. Soejima K, Matsumoto M, Kokame K, Yagi H, Ishizashi H, Maeda $H$, Nozaki C, Miyata T, Fujimura Y, Nakagaki T. ADAMTS-13 cysteine-rich/spacer domains are functionally essential for von Willebrand factor cleavage. Blood. 2003; 102: 3232-7. $\quad$ http://dx.doi.org/10.1182/blood-2003-03-0908 PMid:12869506

57. Ai J, Smith P, Wang S, Zhang P, Zheng XL. The proximal carboxyl-terminal domains of ADAMTS13 determine substrate specificity and are all required for cleavage of von Willebrand factor. J Biol Chem. 2005; 280: 29428-34.

http://dx.doi.org/10.1074/jbc.M505513200 PMid:15975930 PMCid:PMC2577221

58. Xiang Y, de Groot R, Crawley JT, Lane DA. Mechanism of von Willebrand factor scissile bond cleavage by a disintegrin and metalloproteinase with a thrombospondin type 1 motif, member 13 (ADAMTS13). Proc Natl Acad Sci U S A. 2011; 108: $11602-$ 7. http://dx.doi.org/10.1073/pnas.1018559108 PMid:21705658 PMCid:PMC3136259

59. Tsai HM. Shear stress and von Willebrand factor in health and disease. Semin Thromb Hemost. 2003; 29: 479-88. http://dx.doi.org/10.1055/s-2003-44556 PMid:14631548

60. De Cristofaro R, Peyvandi F, Palla R, Lavoretano S, Lombardi R, Merati G, Romitelli F, Di Stasio E, Mannucci PM. Role of chloride ions in modulation of the interaction between von Willebrand factor and ADAMTS-13. J Biol Chem. 2005; 280: 23295-302. http://dx.doi.org/10.1074/jbc.M501143200 PMid:15809291

61. Dong JF, Moake JL, Nolasco L, Bernardo A, Arceneaux W, Shrimpton CN, Schade AJ, McIntire LV, Fujikawa K, Lopez JA. ADAMTS-13 rapidly cleaves newly secreted ultralarge von Willebrand factor multimers on the endothelial surface under flowing conditions. Blood. 2002; 100: 4033-9. http://dx.doi.org/10.1182/blood-2002-05-1401 PMid:12393397

62. Dong JF. Cleavage of ultra-large von Willebrand factor by ADAMTS-13 under flow conditions. J Thromb Haemost. 2005;
3: 1710-6. http://dx.doi.org/10.1111/j.1538-7836.2005.01360.x PMid:16102037

63. Auton M, Cruz MA, Moake J. Conformational stability and domain unfolding of the Von Willebrand factor A domains. J Mol Biol. 2007; 366: 986-1000. http://dx.doi.org/10.1016/j.jmb.2006.10.067 PMid:17187823

64. Majerus EM, Anderson PJ, Sadler JE. Binding of ADAMTS13 to von Willebrand factor. J Biol Chem. 2005; 280: 21773-8. http://dx.doi.org/10.1074/jbc.M502529200 PMid:15824096

65. Moake JL. Thrombotic microangiopathies. N Engl J Med. 2002; 347: 589-600. http://dx.doi.org/10.1056/NEJMra020528 PMid:12192020

66. Nishio K, Anderson PJ, Zheng XL, Sadler JE. Binding of platelet glycoprotein Ibalpha to von Willebrand factor domain A1 stimulates the cleavage of the adjacent domain A2 by ADAMTS13. Proc Natl Acad Sci U S A. 2004; 101: 10578-83. http://dx.doi.org/10.1073/pnas.0402041101 PMid:15249683 PMCid:PMC489977

67. Bernardo A, Ball C, Nolasco L, Moake JF, Dong JF. Effects of inflammatory cytokines on the release and cleavage of the endothelial cell-derived ultralarge von Willebrand factor multimers under flow. Blood. 2004; 104: 100-6. http://dx.doi.org/10.1182/blood-2004-01-0107 PMid:15026315

68. Studt JD, Hovinga JA, Antoine G, Hermann M, Rieger M, Scheiflinger F, Lammle B. Fatal congenital thrombotic thrombocytopenic purpura with apparent ADAMTS13 inhibitor: in vitro inhibition of ADAMTS13 activity by hemoglobin. Blood. 2005; 105: 542-4. http://dx.doi.org/10.1182/blood-200406-2096 PMid:15367436

69. Raife TJ, Cao W, Atkinson BS, Bedell B, Montgomery RR, Lentz SR, Johnson GF, Zheng XL. Leukocyte proteases cleave von Willebrand factor at or near the ADAMTS13 cleavage site. Blood. 2009; 114: 1666-74. http://dx.doi.org/10.1182/blood2009-01-195461 PMid:19541819 PMCid:PMC2731642

70. Chen J, Fu X, Wang Y, Ling M, McMullen B, Kulman J, Chung DW, Lopez JA. Oxidative modification of von Willebrand factor by neutrophil oxidants inhibits its cleavage by ADAMTS13. Blood. 2010; 115: 706-12. http://dx.doi.org/10.1182/blood-200903-213967 PMid:19812385 PMCid:PMC2810979

71. Lancellotti S, De Filippis V, Pozzi N, Peyvandi F, Palla R, Rocca B, Rutella S, Pitocco D, Mannucci PM, De Cristofaro R. Formation of methionine sulfoxide by peroxynitrite at position 1606 of von Willebrand factor inhibits its cleavage by ADAMTS-13: A new prothrombotic mechanism in diseases associated with oxidative stress. Free Radic Biol Med. 2010; 48: 446-56. http://dx.doi.org/10.1016/i.freeradbiomed.2009.11.020 PMid:19969076

72. Lancellotti S, De Filippis V, Pozzi N, Oggianu L, Rutella S, Scaglione GL, Maset F, Peyvandi F, Mannucci PM, De Cristofaro R. Oxidized von Willebrand factor is efficiently cleaved by serine proteases from primary granules of leukocytes: divergence from ADAMTS-13. J Thromb Haemost. 2011; 9: 1620-7. http://dx.doi.org/10.1111/j.1538-7836.2011.04367.x PMid:21605335

73. Wohner N, Kovacs A, Machovich R, Kolev K. Modulation of the von Willebrand factor-dependent platelet adhesion through alternative proteolytic pathways. Thromb Res. 2012; 129: e41-6. http://dx.doi.org/10.1016/j.thromres.2011.11.021 PMid:22178067 PMCid:PMC3323834

74. George JN. Clinical practice. Thrombotic thrombocytopenic purpura. N Engl J Med. 2006; 354: 1927-35. http://dx.doi.org/10.1056/NEJMcp053024 PMid:16672704

75. Silverstein A. Thrombotic thrombocytopenic purpura. The initial neurologic manifestations. Arch Neurol. 1968; 18: 358-62. http://dx.doi.org/10.1001/archneur.1968.00470340044003 PMid:5689024

76. Ruggenenti P, Remuzzi G. Thrombotic microangiopathies. Crit Rev Oncol Hematol. 1991; 11: 243-65. http://dx.doi.org/10.1016/1040-8428(91)90028-B

77. McLeod BC. Thrombotic microangiopathies in bone marrow and organ transplant patients. J Clin Apher. 2002; 17: 118-23. http://dx.doi.org/10.1002/jca.10030 PMid:12378546

78. Asada Y, Sumiyoshi A, Hayashi T, Suzumiya J, Kaketani K Immunohistochemistry of vascular lesion in thrombotic thrombocytopenic purpura, with special reference to factor VIII related antigen. Thromb Res. 1985; 38: 469-79. 
http://dx.doi.org/10.1016/0049-3848(85)90180-X

79. Tsai HM, Chandler WL, Sarode R, Hoffman R, Jelacic S, Habeeb RL, Watkins SL, Wong CS, Williams GD, Tarr PI. von Willebrand factor and von Willebrand factor-cleaving metalloprotease activity in Escherichia coli O157:H7-associated hemolytic uremic syndrome. Pediatr Res. 2001; 49: 653-9. http://dx.doi.org/10.1203/00006450-200105000-00008 PMid: 11328948

80. Hosler GA, Cusumano AM, Hutchins GM. Thrombotic thrombocytopenic purpura and hemolytic uremic syndrome are distinct pathologic entities. A review of 56 autopsy cases. Arch Pathol Lab Med. 2003; 127: 834-9. PMid:12823037

81. Camilleri RS, Cohen H, Mackie IJ, Scully M, Starke RD, Crawley JT, Lane DA, Machin SJ. Prevalence of the ADAMTS13 missense mutation R1060W in late onset adult thrombotic thrombocytopenic purpura. J Thromb Haemost. 2008; 6: 331-8. PMid:18031293

82. Veyradier A, Lavergne JM, Ribba AS, Obert B, Loirat C, Meyer D, Girma JP. Ten candidate ADAMTS13 mutations in six French families with congenital thrombotic thrombocytopenic purpura (Upshaw-Schulman syndrome). J Thromb Haemost. 2004; 2: 424-9. $\quad$ http://dx.doi.org/10.1111/j.15387933.2004.00623.x PMid:15009458

83. Kentouche K, Budde U, Furlan M, Scharfe V, Schneppenheim R, Zintl F. Remission of thrombotic thrombocytopenic purpura in a patient with compound heterozygous deficiency of von Willebrand factor-cleaving protease by infusion of solvent/detergent plasma. Acta Paediatr. 2002; 91: 1056-9. http://dx.doi.org/10.1111/j.1651-2227.2002.tb00099.x PMid:12434890

84. Antoine G, Zimmermann K, Plaimauer B, Grillowitzer M, Studt JD, Lammle B, Scheiflinger F. ADAMTS13 gene defects in two brothers with constitutional thrombotic thrombocytopenic purpura and normalization of von Willebrand factor-cleaving protease activity by recombinant human ADAMTS13. Br J Haematol. 2003; 120: 821-4. http://dx.doi.org/10.1046/j.13652141.2003.04183.x PMid:12614216

85. Assink K, Schiphorst R, Allford S, Karpman D, Etzioni A, Brichard B, van de Kar N, Monnens L, van den Heuvel L. Mutation analysis and clinical implications of von Willebrand factor-cleaving protease deficiency. Kidney Int. 2003; 63: 1995PMid:12753286

http://dx.doi.org/10.1046/j.1523-1755.63.6s.1.x

86. Schneppenheim R, Budde U, Oyen F, Angerhaus D, Aumann V, Drewke E, Hassenpflug W, Haberle J, Kentouche K, Kohne E, Kurnik K, Mueller-Wiefel D, Obser T, Santer R, Sykora KW. von Willebrand factor cleaving protease and ADAMTS13 mutations in childhood TTP. Blood. 2003; 101: 1845-50. http://dx.doi.org/10.1182/blood-2002-08-2399 PMid:12393505

87. Schneppenheim R, Kremer Hovinga JA, Becker T, Budde U, Karpman D, Brockhaus W, Hrachovinova I, Korczowski B, Oyen F, Rittich S, von Rosen J, Tjonnfjord GE, Pimanda JE, Wienker TF, Lammle B. A common origin of the 4143insA ADAMTS13 mutation. Thromb Haemost. 2006; 96: 3-6. PMid: 16807643

88. Savasan S, Lee SK, Ginsburg D, Tsai HM. ADAMTS13 gene mutation in congenital thrombotic thrombocytopenic purpura with previously reported normal VWF cleaving protease activity. Blood. 2003; 101: 4449-51. http://dx.doi.org/10.1182/blood2002-12-3796 PMid:12576319

89. Matsumoto M, Kokame K, Soejima K, Miura M, Hayashi S, Fujii Y, Iwai A, Ito E, Tsuji Y, Takeda-Shitaka M, Iwadate M, Umeyama H, Yagi H, Ishizashi H, Banno F, Nakagaki T, Miyata T, Fujimura Y. Molecular characterization of ADAMTS13 gene mutations in Japanese patients with Upshaw-Schulman syndrome. Blood. 2004; 103: 1305-10. http://dx.doi.org/10.1182/blood-2003-06-1796 PMid:14563640

90. Pimanda JE, Maekawa A, Wind T, Paxton J, Chesterman CN, Hogg PJ. Congenital thrombotic thrombocytopenic purpura in association with a mutation in the second CUB domain of ADAMTS13. Blood. 2004; 103: 627-9.

http://dx.doi.org/10.1182/blood-2003-04-1346 PMid:14512317

91. Uchida $T$, Wada $H$, Mizutani $M$, Iwashita $M$, Ishihara $H$, Shibano T, Suzuki M, Matsubara Y, Soejima K, Matsumoto M, Fujimura Y, Ikeda Y, Murata M. Identification of novel mutations in ADAMTS13 in an adult patient with congenital thrombotic thrombocytopenic purpura. Blood. 2004; 104: 2081 3 PMid:15126318

http://dx.doi.org/10.1182/blood-2004-02-0715

92. Licht C, Stapenhorst L, Simon T, Budde U, Schneppenheim R, Hoppe B. Two novel ADAMTS13 gene mutations in thrombotic thrombocytopenic purpura/hemolytic-uremic syndrome (TTP/HUS). Kidney Int. 2004; 66: 955-8. http://dx.doi.org/10.1111/j.1523-1755.2004.00841.x PMid:15327386

93. Snider CE, Moore JC, Warkentin TE, Finch CN, Hayward CP, Kelton JG. Dissociation between the level of von Willebrand factor-cleaving protease activity and disease in a patient with congenital thrombotic thrombocytopenic purpura. Am J Hematol. 2004; 77: 387-90. http://dx.doi.org/10.1002/ajh.20221 PMid: 15551280

94. Noris M, Bucchioni S, Galbusera M, Donadelli R, Bresin E, Castelletti F, Caprioli J, Brioschi S, Scheiflinger F, Remuzzi G. Complement factor $\mathrm{H}$ mutation in familial thrombotic thrombocytopenic purpura with ADAMTS13 deficiency and renal involvement. J Am Soc Nephrol. 2005; 16: 1177-83. http://dx.doi.org/10.1681/ASN.2005010086 PMid:15800115

95. Liu F, Jin J, Dong NZ, Wang YG, Ruan CG. [Identification of two novel mutations in ADAMTS13 gene in a patient with hereditary thrombotic thrombocytopenic purpura]. Zhonghua Xue Ye Xue Za Zhi. 2005; 26: 521-4. PMid:16468327

96. Donadelli R, Banterla F, Galbusera M, Capoferri C, Bucchioni S, Gastoldi S, Nosari S, Monteferrante G, Ruggeri ZM, Bresin E, Scheiflinger F, Rossi E, Martinez C, Coppo R, Remuzzi G, Noris $\mathrm{M}$. In-vitro and in-vivo consequences of mutations in the von Willebrand factor cleaving protease ADAMTS13 in thrombotic thrombocytopenic purpura. Thromb Haemost. 2006; 96: 454-64. PMid:17003922

97. Palla R, Lavoretano S, Lombardi R, Garagiola I, Karimi M, Afrasiabi A, Ramzi M, De Cristofaro R, Peyvandi F. The first deletion mutation in the TSP1-6 repeat domain of ADAMTS13 in a family with inherited thrombotic thrombocytopenic purpura. Haematologica. 2009; 94: 289-93. http://dx.doi.org/10.3324/haematol.13524 PMCid:PMC2635406

98. Plaimauer B, Fuhrmann J, Mohr G, Wernhart W, Bruno K, Ferrari S, Konetschny C, Antoine G, Rieger M, Scheiflinger F. Modulation of ADAMTS13 secretion and specific activity by a combination of common amino acid polymorphisms and a missense mutation. Blood. 2006; 107: 118-25. http://dx.doi.org/10.1182/blood-2005-06-2482 PMid:16160007

99. Shibagaki Y, Matsumoto M, Kokame K, Ohba S, Miyata T, Fujimura Y, Fujita T. Novel compound heterozygote mutations $(\mathrm{H} 234 \mathrm{Q} / \mathrm{R} 1206 \mathrm{X})$ of the ADAMTS13 gene in an adult patient with Upshaw-Schulman syndrome showing predominant episodes of repeated acute renal failure. Nephrol Dial Transplant. 2006; 21: 1289-92. http://dx.doi.org/10.1093/ndt/gfk072 PMid:16449289

100. Tao Z, Anthony K, Peng Y, Choi H, Nolasco L, Rice L, Moake JL, Dong JF. Novel ADAMTS-13 mutations in an adult with delayed onset thrombotic thrombocytopenic purpura. J Thromb Haemost. 2006; 4: 1931-5. http://dx.doi.org/10.1111/j.15387836.2006.02098.x PMid:16796708

101. Hommais A, Rayes J, Houllier A, Obert B, Legendre P, Veyradier A, Girma JP, Ribba AS. Molecular characterization of four ADAMTS13 mutations responsible for congenital thrombotic thrombocytopenic purpura (Upshaw-Schulman syndrome). Thromb Haemost. 2007; 98: 593-9. PMid:17849048

102. Meyer SC, Jeddi R, Meddeb B, Gouider E, Lammle B, Kremer Hovinga JA. A first case of congenital TTP on the African continent due to a new homozygous mutation in the catalytic domain of ADAMTS13. Ann Hematol. 2008; 87: 663-6. http://dx.doi.org/10.1007/s00277-008-0496-6 PMid:18443791

103. Kokame K, Aoyama Y, Matsumoto M, Fujimura Y, Miyata T. Inherited and de novo mutations of ADAMTS13 in a patient with Upshaw-Schulman syndrome. J Thromb Haemost. 2008; 6: 213-5. $\quad$ http://dx.doi.org/10.1111/j.1538-7836.2007.02828.x PMid:17988227

104. Garagiola I, Valsecchi C, Lavoretano S, Oren H, Bohm M, Peyvandi F. Nonsense-mediated mRNA decay in the ADAMTS13 gene caused by a 29-nucleotide deletion. Haematologica. 2008; 93: 1678-85 
http://dx.doi.org/10.3324/haematol.13102 PMid:18835837

105. Fujimura Y, Matsumoto M, Kokame K, Isonishi A, Soejima K, Akiyama N, Tomiyama J, Natori K, Kuranishi Y, Imamura Y, Inoue $\mathrm{N}$, Higasa S, Seike M, Kozuka T, Hara M, Wada H, Murata M, Ikeda Y, Miyata T, George JN. Pregnancy-induced thrombocytopenia and TTP, and the risk of fetal death, in Upshaw-Schulman syndrome: a series of 15 pregnancies in 9 genotyped patients. Br J Haematol. 2009; 144: 742-54. http://dx.doi.org/10.1111/j.1365-2141.2008.07515.x PMid:19055667

106. Manea M, Kristoffersson A, Tsai HM, Zhou W, Winqvist I, Oldaeus G, Billstrom R, Bjork P, Holmberg L, Karpman D. ADAMTS13 phenotype in plasma from normal individuals and patients with thrombotic thrombocytopenic purpura. Eur J Pediatr. 2007; 166: 249-57. http://dx.doi.org/10.1007/s00431006-0354-2 PMid:17187257 PMCid:PMC1820762

107. Motto DG, Chauhan AK, Zhu G, Homeister J, Lamb CB, Desch KC, Zhang W, Tsai HM, Wagner DD, Ginsburg D. Shigatoxin triggers thrombotic thrombocytopenic purpura in genetically susceptible ADAMTS13-deficient mice. J Clin Invest. 2005; 115: 2752-61. http://dx.doi.org/10.1172/JCI26007 PMid:16200209 PMCid:PMC1240119

108. Banno F, Kokame K, Okuda T, Honda S, Miyata S, Kato H, Tomiyama Y, Miyata T. Complete deficiency in ADAMTS13 is prothrombotic, but it alone is not sufficient to cause thrombotic thrombocytopenic purpura. Blood. 2006; 107: 3161-6. http://dx.doi.org/10.1182/blood-2005-07-2765 PMid:16368888

109. Nolasco LH, Turner NA, Bernardo A, Tao Z, Cleary TG, Dong JF, Moake JL. Hemolytic uremic syndrome-associated Shiga toxins promote endothelial-cell secretion and impair ADAMTS13 cleavage of unusually large von Willebrand factor multimers. Blood. 2005; 106: 4199-209.

http://dx.doi.org/10.1182/blood-2005-05-2111 PMid:16131569 PMCid:PMC1895236

110. Tao Z, Peng Y, Nolasco L, Cal S, Lopez-Otin C, Li R, Moake JL, Lopez JA, Dong JF. Recombinant CUB-1 domain polypeptide inhibits the cleavage of ULVWF strings by ADAMTS13 under flow conditions. Blood. 2005; 106: 4139-45. http://dx.doi.org/10.1182/blood-2005-05-2029 PMid:16141351 PMCid:PMC1895231

111. Tsai HM. Pathophysiology of thrombotic thrombocytopenic purpura. Int J Hematol. 91: 1-19. http://dx.doi.org/10.1007/s12185-009-0476-1 PMid:20058209 PMCid:PMC3159000

112. Jang MJ, Kim NK, Chong SY, Kim HJ, Lee SJ, Kang MS, Oh D. Frequency of Pro475Ser polymorphism of ADAMTS13 gene and its association with ADAMTS-13 activity in the Korean population. Yonsei Med J. 2008; 49: 405-8.

http://dx.doi.org/10.3349/ymi.2008.49.3.405 PMid:18581589 PMCid:PMC2615352

113. Akiyama M, Kokame K, Miyata T. ADAMTS13 P475S polymorphism causes a lowered enzymatic activity and urea lability in vitro. J Thromb Haemost. 2008; 6: 1830-2. http://dx.doi.org/10.1111/j.1538-7836.2008.03109.x PMid:18665921

114. Borgi A, Khemiri M, Veyradier A, Kazdaghli K, Barsaoui S. Congenital Thrombotic Thrombocytopenic Purpura: Atypical Presentation and New ADAMTS 13 Mutation in a Tunisian Child. Mediterr J Hematol Infect Dis. 2013; 5: e2013041. http://dx.doi.org/10.4084/mjhid.2013.041

PMid:23795279 PMCid:PMC3684349

115. Sadler JE, Moake JL, Miyata T, George JN. Recent advances in thrombotic thrombocytopenic purpura. Hematology Am Soc Hematol Educ Program. 2004: 407-23. http://dx.doi.org/10.1182/asheducation-2004.1.407 PMid:15561695

116. Veyradier A, Obert B, Houllier A, Meyer D, Girma JP. Specific von Willebrand factor-cleaving protease in thrombotic microangiopathies: a study of 111 cases. Blood. 2001; 98: 176572. http://dx.doi.org/10.1182/blood.V98.6.1765 PMid:11535510

117. Coppo P, Bengoufa D, Veyradier A, Wolf M, Bussel A, Millot GA, Malot S, Heshmati F, Mira JP, Boulanger E, Galicier L, Durey-Dragon MA, Fremeaux-Bacchi V, Ramakers M, Pruna A, Bordessoule D, Gouilleux V, Scrobohaci ML, Vernant JP, Moreau D, Azoulay E, Schlemmer B, Guillevin L, Lassoued K. Severe ADAMTS13 deficiency in adult idiopathic thrombotic microangiopathies defines a subset of patients characterized by various autoimmune manifestations, lower platelet count, and mild renal involvement. Medicine (Baltimore). 2004; 83: 233 44. http://dx.doi.org/10.1097/01.md.0000133622.03370.07

118. Zheng XL, Kaufman RM, Goodnough LT, Sadler JE. Effect of plasma exchange on plasma ADAMTS13 metalloprotease activity, inhibitor level, and clinical outcome in patients with idiopathic and nonidiopathic thrombotic thrombocytopenic purpura. Blood. 2004; 103: 4043-9. http://dx.doi.org/10.1182/blood-2003-11-4035 PMid:14982878

119. Rieger M, Mannucci PM, Kremer Hovinga JA, Herzog A, Gerstenbauer G, Konetschny C, Zimmermann K, Scharrer I, Peyvandi F, Galbusera M, Remuzzi G, Bohm M, Plaimauer B, Lammle B, Scheiflinger F. ADAMTS13 autoantibodies in patients with thrombotic microangiopathies and other immunomediated diseases. Blood. 2005; 106: 1262-7. http://dx.doi.org/10.1182/blood-2004-11-4490 PMid:15890682

120. Mannucci PM. Thrombotic thromboytopenic purpura: another example of immunomediated thrombosis. Pathophysiol Haemost Thromb. 2006; 35: 89-97. http://dx.doi.org/10.1159/000093549 PMid:16855352

121. Mannucci PM, Bohm M, Scharrer I, Scheiflinger F. Patterns of changes of anti-ADAMTS13 after plasma exchange. J Thromb Haemost. 2006; 4: 1405-6. http://dx.doi.org/10.1111/j.15387836.2006.01960.x PMid:16706988

122. Waters B, Qadura M, Burnett E, Chegeni R, Labelle A, Thompson P, Hough C, Lillicrap D. Anti-CD3 prevents factor VIII inhibitor development in hemophilia A mice by a regulatory CD4+CD25+-dependent mechanism and by shifting cytokine production to favor a Th1 response. Blood. 2009; 113: 193-203. http://dx.doi.org/10.1182/blood-2008-04-151597 PMid:18815284

123. Terrell DR, Williams LA, Vesely SK, Lammle B, Hovinga JA, George JN. The incidence of thrombotic thrombocytopenic purpura-hemolytic uremic syndrome: all patients, idiopathic patients, and patients with severe ADAMTS-13 deficiency. J Thromb Haemost. 2005; 3: 1432-6. http://dx.doi.org/10.1111/j.1538-7836.2005.01436.x PMid:15978100

124. Ferrari S, Mudde GC, Rieger M, Veyradier A, Kremer Hovinga JA, Scheiflinger F. IgG subclass distribution of antiADAMTS13 antibodies in patients with acquired thrombotic thrombocytopenic purpura. J Thromb Haemost. 2009; 7: 1703 10. http://dx.doi.org/10.1111/j.1538-7836.2009.03568.x PMid: 19682238

125. Dong L, Chandrasekaran V, Zhou W, Tsai HM. Evolution of ADAMTS13 antibodies in a fatal case of thrombotic thrombocytopenic purpura. Am J Hematol. 2008; 83: 815-7. http://dx.doi.org/10.1002/ajh.21217

PMid:18661493 PMCid:PMC2574606

126. Zhou W, Dong L, Ginsburg D, Bouhassira EE, Tsai HM. Enzymatically active ADAMTS13 variants are not inhibited by anti-ADAMTS13 autoantibodies: a novel therapeutic strategy? J Biol Chem. 2005; 280: 39934-41. http://dx.doi.org/10.1074/jbc.M504919200 PMid:16203734 PMCid:PMC2582217

127. Tsai HM, Li A, Rock G. Inhibitors of von Willebrand factorcleaving protease in thrombotic thrombocytopenic purpura. Clin Lab. 2001; 47: 387-92. PMid:11499801

128. Favaloro EJ, Bonar R, Kershaw G, Duncan E, Sioufi J, Marsden $\mathrm{K}$. Investigations from external quality assurance programs reveal a high degree of variation in the laboratory identification of coagulation factor inhibitors. Semin Thromb Hemost. 2009; 35: 794-805. http://dx.doi.org/10.1055/s-0029-1245112 PMid:20169516

129. Yomtovian R, Niklinski W, Silver B, Sarode R, Tsai HM Rituximab for chronic recurring thrombotic thrombocytopenic purpura: a case report and review of the literature. $\mathrm{Br} \mathrm{J}$ Haematol. 2004; 124: 787-95. http://dx.doi.org/10.1111/j.13652141.2004.04836.x PMid:15009067 PMCid:PMC3153075

130. Saito I, Folsom AR, Brancati FL, Duncan BB, Chambless LE, McGovern PG. Nontraditional risk factors for coronary heart disease incidence among persons with diabetes: the Atherosclerosis Risk in Communities (ARIC) Study. Ann Intern Med. 2000; 133: 81-91. http://dx.doi.org/10.7326/0003-4819133-2-200007180-00007 PMid:10896647 
131. Spiel AO, Gilbert JC, Jilma B. von Willebrand factor in cardiovascular disease: focus on acute coronary syndromes. Circulation. 2008; 117: 1449-59.

http://dx.doi.org/10.1161/CIRCULATIONAHA.107.722827 PMid:18347221

132. Frankel DS, Meigs JB, Massaro JM, Wilson PW, O'Donnell CJ, D'Agostino RB, Tofler GH. Von Willebrand factor, type 2 diabetes mellitus, and risk of cardiovascular disease: the framingham offspring study. Circulation. 2008; 118: 2533-9. http://dx.doi.org/10.1161/CIRCULATIONAHA.108.792986 PMid:19029465 PMCid:PMC2746947

133. Hanson E, Jood K, Karlsson S, Nilsson S, Blomstrand C, Jern C. Plasma levels of von Willebrand factor in the etiologic subtypes of ischemic stroke. J Thromb Haemost. 2011; 9: 275-81. http://dx.doi.org/10.1111/j.1538-7836.2010.04134.x PMid:21054779

134. Wieberdink RG, van Schie MC, Koudstaal PJ, Hofman A, Witteman JC, de Maat MP, Leebeek FW, Breteler MM. High von Willebrand factor levels increase the risk of stroke: the Rotterdam study. Stroke. 2010; 41: 2151-6.
http://dx.doi.org/10.1161/STROKEAHA.110.586289 PMid:20798373

135. Oggianu L, Lancellotti S, Pitocco D, Zaccardi F, Rizzo P, Martini F, Ghirlanda G, De Cristofaro R. The oxidative modification of von Willebrand factor is associated with thrombotic angiopathies in diabetes mellitus. PLoS One. 2013; 8: e55396. $\quad$ http://dx.doi.org/10.1371/journal.pone.0055396 PMid:23383177 PMCid:PMC3561310

136. De Filippis V, Lancellotti S, Maset F, Spolaore B, Pozzi N, Gambaro G, Oggianu L, Calo LA, De Cristofaro R. Oxidation of Met1606 in von Willebrand factor is a risk factor for thrombotic and septic complications in chronic renal failure. Biochem $\mathrm{J}$. 2012; 442: 423-32. http://dx.doi.org/10.1042/BJ20111798 PMid:22091998

137. Wada H, Kaneko T, Ohiwa M, Tanigawa M, Tamaki S, Minami N, Takahashi H, Deguchi K, Nakano T, Shirakawa S. Plasma cytokine levels in thrombotic thrombocytopenic purpura. Am J Hematol. 1992; 40: 167-70.

http://dx.doi.org/10.1002/ajh.283040030 3 PMid:1609769 